\title{
Muebles virreinales oaxaqueños realizados en zumaque. La marquetería de Villa Alta ${ }^{1}$
}

\section{Viceregal furniture from Oaxaca carried out in zumaque. The marquetry of Villa Alta}

\author{
Juan Manuel Corrales \\ Galería de Palacio Nacional. Ciudad de México
}

\section{RESUMEN}

La región mexicana de Oaxaca, durante el periodo virreinal, fue un gran centro productor de muebles. De entre los diversos trabajos oaxaqueños destacan los realizados con una técnica particular de la zona serrana denominada, comúnmente, zumaque. Estas producciones realizadas en la Villa Alta de San Ildefonso, entre los siglos XVII al XIX, se limitan exclusivamente a ciertas tipologías de muebles civiles; escritorios, papeleras, escritorillos o arquillas de estrado, arcas, arquetas y cajas. Este artículo presenta la investigación más reciente y completa sobre el tema adentrándose en la problemática terminológica, los orígenes del centro productor, las diversas técnicas constructivas y decorativas empleadas así como el estudio analítico de sus maderas y la pasta de relleno.

Palabras clave: Mueble virreinal, Resina vegetal, México, Modelos europeos, Siglo XVIII.

\section{SUMMARY}

During the Viceregal period, the Mexican region of Oaxaca was a major furniture production center. Among the diverse Oaxacan works those executed in a technique specific to the mountain region commonly known as zumaque stand out. These pieces made in the Villa Alta de San Ildefonso during the $17^{\text {th }}$ to $19^{\text {th }}$ centuries are limited to

${ }^{1}$ Agradezco la colaboración de las siguientes personas: María Paz Aguiló, Virginia Armella, Teresa Calero, Mariana Castillo, Paloma Cuesta, Gustavo Curiel, Dona Donadio, Rosa Dopazo, Ignasi Girones, Gustavo Guevara, Mónica Martí, Ana Ortiz, Alejandra Quintanar, Sofía Rodríguez Bernis, Eumelia Hernández, Rodrigo Rivero-Lake, Alberto RojasHernández Salvador Rueda, Mario S. Somera, Guillermo Tovar de Teresa, Jorge Vertiz, Michel Zabe y Sandra Zetina. 
certain types of civil furniture: writing desks, papeleras, little desks and chests for female use, coffers, little chests and boxes. This article offers the most recent and complete research on the subject and deals with the problematic terminology, the origins of this production center, the diverse construction and decorative techniques utilized and the analytic study of the wood and fillers employed.

Key words: Viceregal Furniture, Vegetable Resin, Mexico, European Models, $18^{\text {th }}$ Century.

\section{INTRODUCCIÓN}

Las diversas culturas prehispánicas contaban, antes de la llegada de Hernán Cortés en 1519, con escasas piezas de mobiliario en palacios y casas. El arribo de mobiliario español posibilitó que tanto los maestros carpinteros españoles como los aprendices indígenas tuvieran modelos que reproducir, y así abastecer la demanda de una incipiente sociedad hispánica que pretendía emular los lujos de la metrópoli (Armiño 1966). Poco a poco, se combinaron las técnicas de carpintería europeas con las técnicas decorativas que tuvieron sus orígenes en el México prehispánico, dando inicio al rico mestizaje cultural en las artes decorativas y suntuarias novohispanas presentes en los hogares criollos.

Dentro de las piezas de mobiliario que durante el siglo XVI llegaron a territorio novohispano destacan por su importancia los escritorios, las papeleras y las arcas (Corrales 2006). Los dos primeros muebles eran emblemáticos de cualquier casa que se preciara, remitiéndonos a universos epistémicos donde los objetos eran símbolo de origen social, moral y de distinción, unidos a la ritualidad y a cierto lenguaje propio (Carrillo 1957). Junto a ellos, las arcas ofrecían a sus propietarios una forma de guardar enseres y tejidos.

El establecimiento de la navegación regular con las Filipinas en 1573 dio paso a un fluido comercio oriental ${ }^{2}$, dando inicio al lujo exótico de las casas virreinales. En cualquier morada de altos recursos económicos del siglo XVII coexistían muebles y objetos europeos, asiáticos y los producidos en este territorio, creándose un peculiar gusto tripartito (Curiel 1994, 1999, 2003, y 2005: 81), al que puede agregarse el gusto por los muebles sudamericanos provenientes de Perú y los caribeños de Cuba. Bernardo de Balbuena expresa en este excepcional soneto, recogido por Benítez (1953: 63-64), los ideales y alcances del imperio español con relación a México:

En ti se juntan España con la China, Italia con Japón y finalmente un mundo entero en trato y disciplina.

${ }^{2}$ A través de la ruta del Galeón de Manila o Nao de China, de la que Schurtz (1992: 203-229) detalla el recorrido. 
Esta exuberancia artística se verá reflejada en el mobiliario de las casas desde el inicio de las rutas comerciales (Rojas, Rea y Medina 1998; Romero de Terreros 1913, 1957), como bien ejemplifica Gómez (1983) en su obra El mobiliario y la decoración en la Nueva España en el siglo XVI.

\section{EL ZUMAQUE}

El zumaque es conocido como una técnica decorativa particular de los muebles novohispanos realizados en la región de Oaxaca entre los siglos XVII y XIX. Se empleó únicamente en la decoración de escritorios, papeleras, escritorillos de estrado, baúles, cajas, arcas, arquetas, cofrecillos, y baulillos de uso civil. En el ámbito religioso se conservan algunas cruces y cajas aisladas, llamando la atención el excepcional conjunto que atesora la iglesia de Tlacochahuaya, también en el estado de Oaxaca, por la singularidad que presentan el púlpito, el facistol, la balaustrada del coro y dos armarios de sacristía, todos ellos realizados con esta técnica, siendo estas las únicas piezas de este tipo que se conocen y conservan como grupo o ajuar en el templo para el que fueron realizados.

Según la tradición, la técnica consiste en recortar chapas y reengruesos ${ }^{3}$ - según la época- de maderas diversas, sobre los que, para evitar que se abran o astillen, se realizan incisiones y desbastes poco profundos, mediante buriles de diferente calibre, según un diseño preestablecido, que se rellenan de una pasta, hasta ahora llamada zumaque, que delimita y realza los diseños incisos en la madera. En esta investigación se ha constatado el empleo de chapas y reengruesos de madera de zumaque, género Rhus, nunca antes estudiado, para ocultar las maderas comunes con que están construidos estos muebles zumacados, ello provoca una gran confusión en cuanto al origen, la técnica y la terminológica que el presente artículo intentará aclarar.

\section{PROBLEMÁticA TERMINOLÓGICA Y ORIGEN}

Existe una gran incertidumbre en relación con el origen de esta técnica y su nomenclatura. Armella (1994: 60-77) clasifica estos trabajos como labores de nielado, técnica decorativa empleada en metalurgia mediante la cual se logran decoraciones en hueco rellenas con esmalte negro que suelen estar realizadas en plata y plomo fundidos con azufre sobre el metal (Diccionario 2001). Aunque el resultado decorativo pudiera ser parecido a los traba-

\footnotetext{
${ }^{3}$ Las chapas tienen un grueso inferior a dos milímetros, a partir de este grosor se trata de reengruesos (Rodríguez 2006: 106 y 285).
} 
jos en madera, no tiene ninguna similitud al tratarse de materiales y técnicas muy diferentes, con tratamientos decorativos distintos. Una definición similar es referida por Gámez (2002: 56) al describir la técnica de un escritorillo oaxaqueño decorado con zumaque perteneciente al Museo José Luis Bello y González, en Puebla. En iguales términos se pronuncia Zahar (2000: 71), al hablar de la taracea en México, comparando los trabajos en zumaque con el nielado.

Carlos Ovando (1962: 62) se refiere a esta técnica como combinaciones de dibujos grabados y quemados, aludiendo al pirograbado. Sin embargo, en estos muebles, los diseños nunca están quemados o grabados, sino excavados y rellenos; además, en los ejemplares más tempranos, del siglo XVII, se emplean diversas gamas cromáticas combinadas con el negro. El pirograbado es una técnica decorativa que presenta un terminado distinto, por lo que no es correcto emplear los términos grabado o quemado para referirse al zumaque.

En cuanto al origen de esta técnica, Armella (1994: 23 y 49) sugiere la influencia ejercida por los talleres y ebanistas alemanes que trabajaron en la Península Ibérica en el zumaque oaxaqueño relacionándolos con los escritorios de marquetería bávara de los siglos XVI y XVII, que presentan perspectivas arquitectónicas y paisajes mediante la contraposición de diversas maderas teñidas y en color natural (Fig. 1). Curiel por su parte (2003: 137) también relaciona los trabajos en zumaque oaxaqueños con la llegada de cajas de Alemania (Augsburgo y Nuremberg) al Virreinato, pero en realidad las labores de los ebanistas alemanes, de delicadas y precisas composiciones creadas con gran maestría técnica, carecen de incisiones y rellenos de pasta por lo que no se asemejan a los trabajos novohispanos en zumaque, en cuyas decoraciones chapadas, además, es habitual la presencia de taquetillos para evitar deformaciones. Por el contrario, sí pueden relacionarse los trabajos de marquetería ecuatoriana, de los siglos XVIII y XIX, en los que las vistas arquitectónicas de ciudades, con varios planos de perspectivas, son mucho más afines en técnica y diseño a los trabajos marqueteados bávaros (Fig. 2).

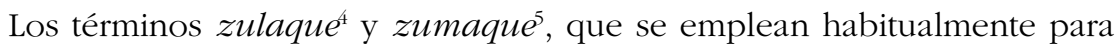
nombrar esta técnica, suelen aparecer escritos tanto con z como con s, aumentando la confusión. Al no encontrarse documentos antiguos novohispanos que hagan referencia a estos términos aplicados a la decoración de este tipo

\footnotetext{
${ }^{4}$ En el catálogo de la exposición Grandeza Mexicana Virreinal, Curiel (2003: 36), al describir uno de estos muebles oaxaqueños, perteneciente al Museo Franz Mayer, nombra la técnica como zulaque.

${ }^{5}$ En el libro aniversario de los veinte años del Museo Franz Mayer. Curiel (2006: 344) describe la técnica de uno de estos muebles oaxaqueños como zumaque.
} 


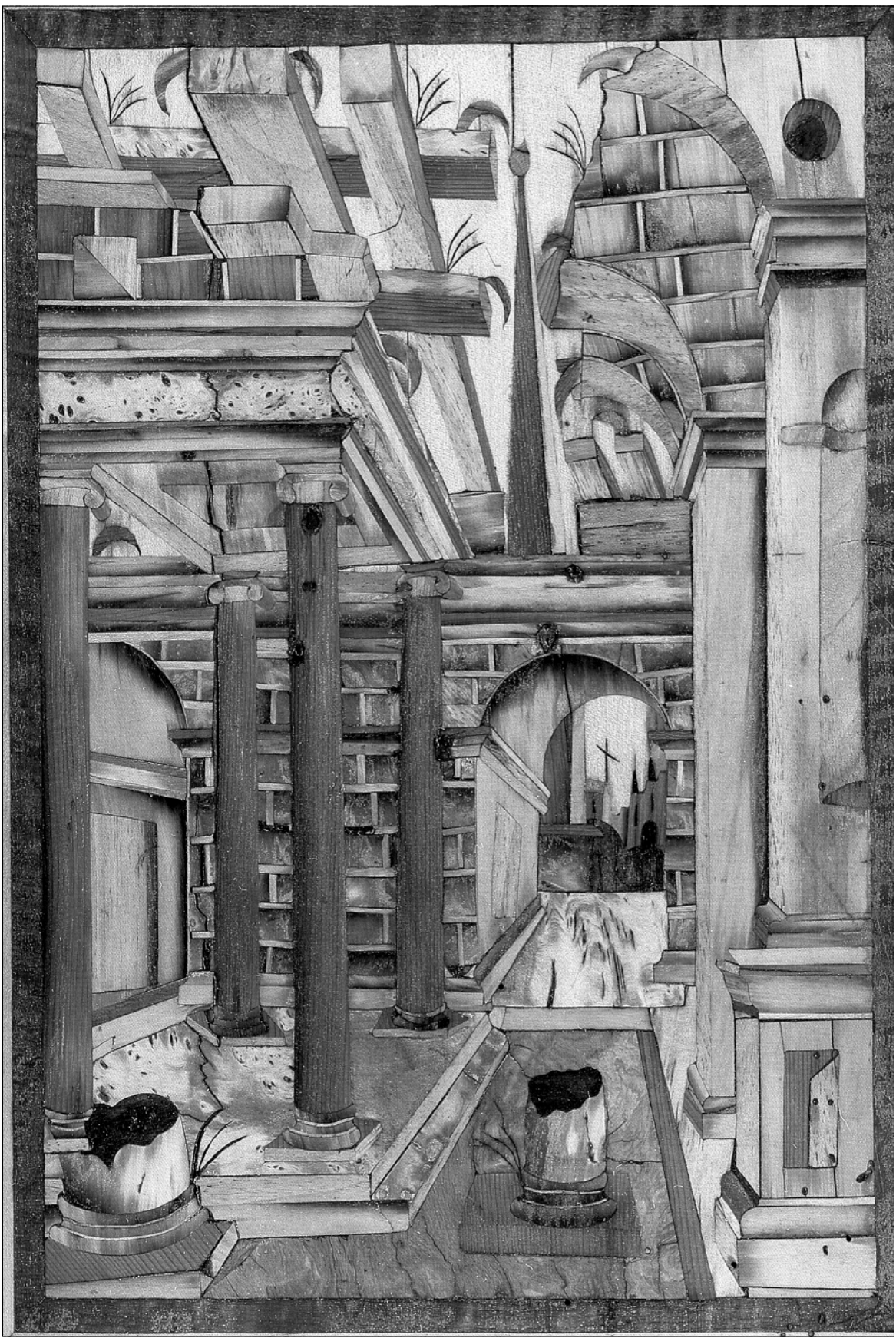

Figura 1. Detalle, escritorio alemán, siglo XviI. Museo Franz Mayer, México. (CBD-0022). 


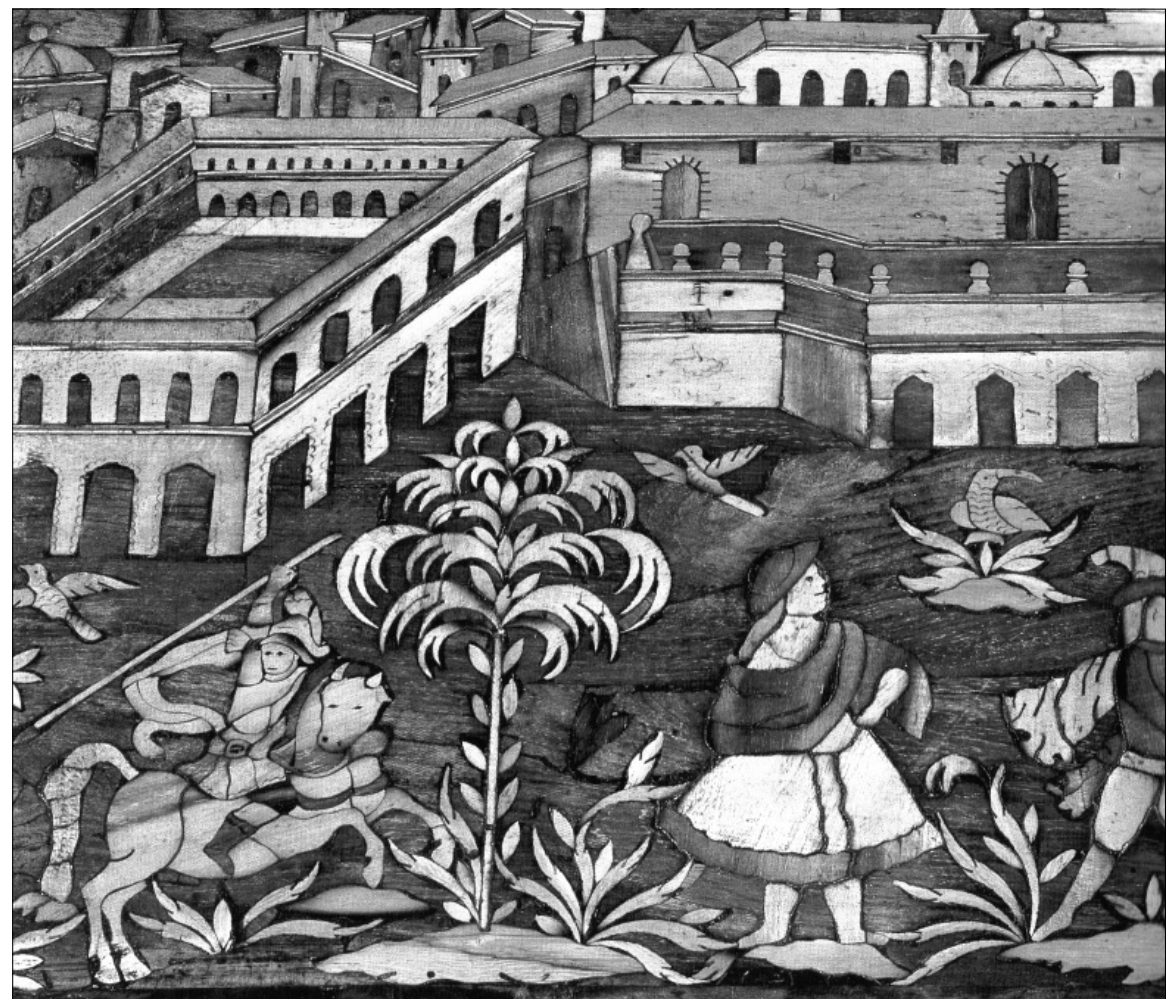

FIgura 2. Detalle, cómoda escritorio, Ecuador, siglo XVIII. Museo Franz Mayer, México. (CES-0007).

de muebles oaxaqueños, resulta más difícil aún puntualizar la terminología correcta.

Analizando y estudiando ambas palabras para definir su relación con esta técnica encontramos que el Diccionario de Autoridades (1726-1739) no incluye zumaque y define el zulaque como 'betún'. Una definición similar es recogida por García Salinero (1968: 457-465) El Diccionario de la Lengua Española (2001) define el término zulaque como:

Betún en pasta hecho con estopa, cal, aceite y escorias o vidrios molidos, a propósito para tapar las juntas de los arcaduces en las cañerías de agua y para otras obras hidráulicas.

El betún es el nombre genérico de una sustancia compuesta principalmente por carbono e hidrógeno que se encuentra en la naturaleza y que en México recibe el nombre de chapapote ${ }^{6}$. Analizando las expresiones

\footnotetext{
${ }^{6}$ Referido en el tratado sobre pegamentos, gomas y resinas del México prehispánico, (Martínez 1974: 125). Su origen etimológico proviene del náhuartl chapopohtli o chapupubtli (Montemayor 2007: 38).
} 
populares españolas recogidas por Urdiales (2006: 332) en su Diccionario, encontramos que tiene el significado ya mencionado. Como se ha podido comprobar, el zulaque era un tipo de pasta utilizada para evitar las filtraciones de agua. Dicha materia se empleaba también en todo lo relacionado con la arquitectura vinculada con el agua, como refiere López Moreno (2005: 163-170) al hablar del espigón y murallas de Punta Cantera en Cádiz:

Todas las piedras exteriores serían labradas convenientemente, adheridas con mortero hidráulico y con las uniones selladas con zulaque.

Esta misma pasta era preparada para aislar las juntas de los sillares que formaban los aljibes y para la reparación de ollas y cazuelas según la tradición popular. En México se emplea una pasta similar en la que se mezcla sebo amasado con cal y pelos de burro o gato como aislante en las construcciones hidráulicas ${ }^{7}$.

En un documento naval, el general Antonio de Ullóa (1784: fol.12), marqués de González de Castejón, describe, ante el Consejo de Guerra, cómo algunos navíos llevaban en sus cargas zulaque:

Habiendo reconocido la vela, se halló ser portuguesa, nombrada Nuestra Señora de la Gloria, su capitán, Miguel Arnauz, hace 8 días salió de Oporto con carga de zulaque.

Todos estos datos demuestran que el término zulaque no puede ser empleado para definir y nombrar la técnica decorativa del mueble que estamos estudiando.

Castelló (1972: 40-41) y otros autores, al hablar de las lacas y el maque ${ }^{8}$ mexicanos de Chiapa de Corzo, emplean el término sulaque para referirse a una pasta hecha con polvo de tiza, del náhuatl tizatle o tizatl ${ }^{\text {, que se }}$ bate en agua de aje o axe, sustancia grasa que se obtiene de las hembras de un insecto hemíptero llamado Coccus axin que vive en los árboles (Montemayor 2007: 23), y cuya grasa tiene propiedades mordentes que empleaban los naturales de estas tierras en la preparación de las piezas que se van a laquear para tapar los poros y las imperfecciones. Estos procesos ya fueron descritos por Hernández (1959: 384) y Sahagún (1956: 139-140).

\footnotetext{
7 Véase Armijo (2005: 92) quien al hablar del acueducto de Chapultepec en la época virreinal hace referencia a este tipo de argamasa hidráulica.

${ }^{8}$ En las regiones del sur de México, es común el empleo de este término para definir un tipo de laca muy particular y común, empleada en la decoración de objetos y muebles, Thiele (1982: 35-42).

9 Arcilla terrosa blanca de magnesio similar al blanco de España, Diccionario (1982: 582).
} 
El Diccionario de la Lengua Española (2001) no define sulaque y dice del maque que es como laca o barniz, zumaque del Japón, relacionándolo con los trabajos laqueados orientales. En Nueva España, desde los trabajos precortesianos, referidos por Pérez (1990: 23-30) hasta la llegada de artesanos orientales, en la Nao de China a partir el siglo XVI y sobre todo en el siglo XVIII, existe una gran tradición de estos acabados decorativos. Los barnices orientales se realizan, desde tiempos remotos, gracias a la sabia de un arbusto, del género Rhus, similar al zumaque, por lo que, muy probablemente, la palabra maque derive del término zumaque.

Sobre el zulaque, Loyzaga (1985: 87), recoge la descripción que hace Behrens de esta técnica aplicada a la decoración de las producciones oaxaqueñas:

Pasta hecha de pelo de chivo, cal, carbón vegetal y aceite de linaza, con la cual se forman hilos que se insertan a presión en las ranuras de la madera taraceada, destinados a la formación de motivos decorativos. Se sustituye el carbón vegetal con materiales colorantes, en el caso que dichos motivos lo requieran.

Armella (1994: 70), recoge una receta muy similar del zulaque, como una mezcla de betún, pelo de chivo y tinta de huizache, al igual que Martínez del Río (1990: 440). Llama la atención el empleo de dos tintes negros: el betún, del que ya hemos hablado con anterioridad; y el buizache o Acacia farnesiana que es un arbusto, endémico de México, de cuyas vainas y raíces se extrae un tinte negro (Prieto 2006), el buitz-ixachi, empleado en la escritura, la elaboración de códices y en las lacas o maque por su intenso color, (Montemayor 2007: 69).

Resulta difícil la aplicación de estas recetas en los delicados trazos incisos de las piezas zumacadas del siglo XVII (Fig. 3), ya que al ser tan sutiles no permiten la colocación de una pasta compuesta con pelos, y menos la aplicación pelo por pelo o en hilos en cada incisión, a no ser que los pelos estén molidos en la mezcla y esta sea muy fina. El pelo formado por queratina, sustancia albuminoide rica en azufre, pudiera emplearse en este compuesto para otorgarle mayor dureza y resistencia. En los trabajos más populares del siglo XVIII (Fig. 4), en los que los espacios incisos son de mayor tamaño y más profundo, siempre en negro, sí es posible incluir estos compuestos, ya que en los ejemplares estudiados se aprecian ciertas craqueladuras en la pasta.

Sería necesario realizar un muestreo de la pasta de relleno para analizarlo químicamente y poder determinar su composición, ya que la queratina, junto con el calcio y el fosfato son unos de los componentes que dan fuerza y rigidez a los huesos, por lo que pudiera emplearse en esta mezcla con ese fin. Se han comprobado ciertas características físicas del zumaque entre 


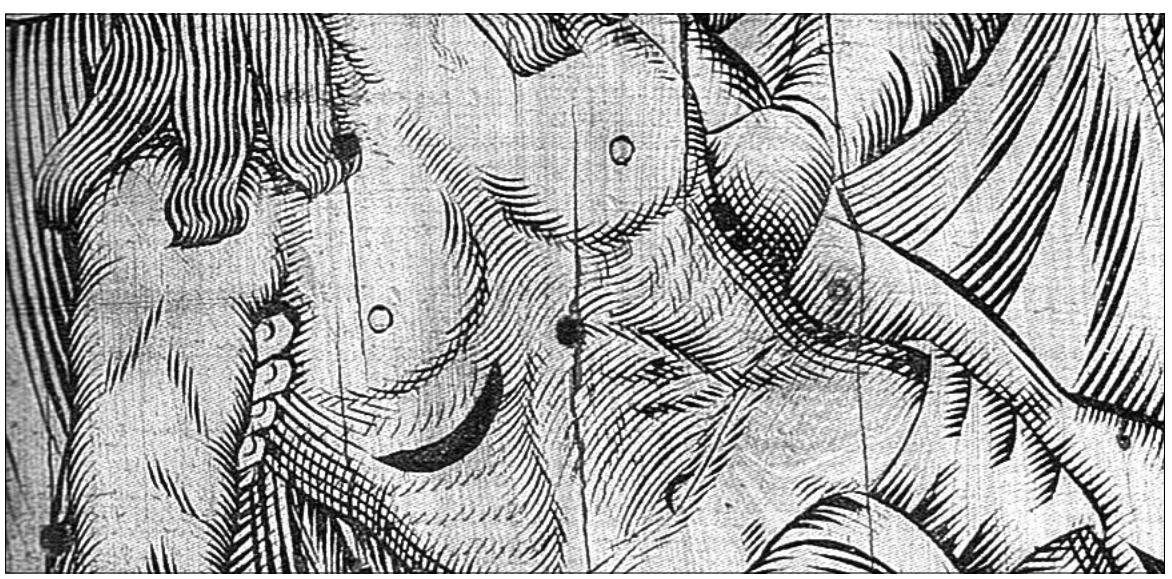

Figura 3. Detalle, baúl oaxaqueño, decoración en zumaque, siglo XVII. Colección particular, México.

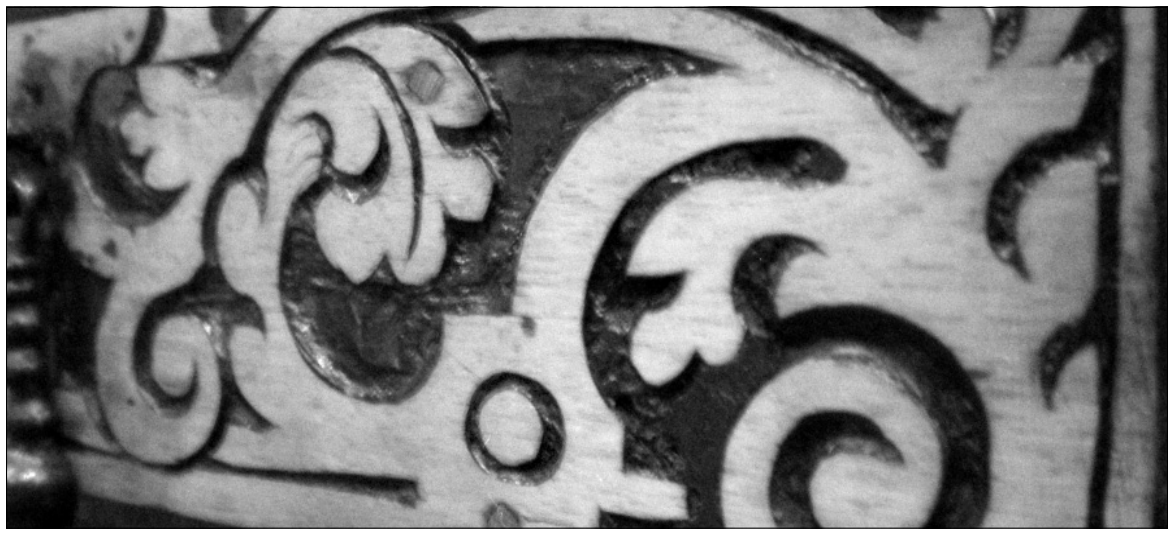

FiguRA 4. Detalle, escritorio oaxaqueño, decoración en zumaque, siglo XVIII. Museo Franz Mayer, México. (CBD-0030).

las que la dureza de la pasta es una de sus mayores cualidades. A ellas pueden agregarse la resistencia a los movimientos de la madera, el ser impermeable al agua y otros líquidos, ser suave al tacto, denso y compacto, con gran estabilidad y brillo intenso, presentando ligeras craqueladuras y resquebrajamientos por el paso del tiempo, con una apariencia similar al lacre $^{10}$ y a las lacas. Los componentes de las dos recetas mencionadas de zulaque son muy similares a las referidas en el sulaque hidráulico; de ello

\footnotetext{
${ }^{10}$ Compuesto por sebo, carbonato de cal, cera y colorante (Blanco 1919: 343-347).
} 
debe provenir el erróneo uso de estas palabras para referirse a la pasta de relleno de los objetos zumacados.

Tanto Loyzaga (1985: 73-90) como Zahar (2000: 71) clasifican este trabajo como taracea, técnicamente relacionada con el recubrimiento mediante chapas, chapeado o enchapado, de la marquetería por el tamaño y la disposición de las piezas empleadas ${ }^{11}$. Zahar también vincula la técnica oaxaqueña con el esgrafiado y la intarsia. Del esgrafiado Sofía Rodríguez Bernis (2006: 166) dice que son incisiones realizadas en la madera que se entintan con sulaque, tinte vegetal, que confiere un aspecto parecido al grabado. El esgrafiado en los muebles está íntimamente relacionado con las producciones italianas del Cuatrocento, como lo refiere Aguiló (1993: 162) al hablar de la tarsia y grafito, diciendo de ella que es una técnica en la que las líneas incisas son marcadas mediante estuco oscurecido. Si bien el estuco no se emplea en el zumaque, la técnica tiene mucho parecido, aunque el Diccionario de la Lengua Española (2001) nos dice que esgrafiar es trazar dibujos con el garfio o punzón con el que, sobre una superficie estofada, se hacen dibujos y labores, haciendo saltar algunas capas superficiales dejando así al descubierto el o los colores siguientes. Para evitar posibles confusiones, parece lógico referirse a esta técnica como labor incisa y no esgrafiada.

Hay quienes relacionan esta técnica decorativa del mueble oaxaqueño con la llegada de la primera imprenta a Guatemala ${ }^{12}$. Esta hipótesis asocia el entintado y el tallado de las letras en madera de la imprenta con el zumaque, por la influencia que hubiera ejercido el camino recorrido por la primera imprenta guatemalteca a su paso por estas tierras oaxaqueñas: desde la ciudad de Puebla de los Ángeles, donde fue adquirida por fray Francisco de Borja, entre 1659 y 1660, hasta su llegada a Santiago de Guatemala, como figura en la descripción de Tlaxcala de Muñoz (2000: 17). Parece poco probable que el paso de la imprenta por la región influyera en este nuevo estilo decorativo del mueble oaxaqueño; si a ello agregamos que se conservan piezas en zumaque, con motivos renacentistas y platerescos, realizadas desde la primera mitad del siglo XVII la hipótesis pierde validez.

El Diccionario de la Lengua Española (2001) define el zumaque con varias acepciones; la que interesa aquí "Zumaque del Japón. Sustancia

${ }^{11}$ El término taracea (Autoridades 1726: 460), es un adorno de una cosa de dos colores hecho como a manchas con proporción y hermosura. Su empleo ha sido confuso en los documentos antiguos, aunque la gran mayoría de los investigadores lo relacionan con la marquetería, otros, por el contrario, lo asocian con el embutido sobre madera. Véase Rodríguez (2006: 323).

${ }^{12}$ Entre ellos el historiador mexicano Guillermo Tovar de Teresa quien me lo ha manifestado en diversas conversaciones mantenidas sobre el origen de esta técnica. 
resinosa afín a la laca, segregada por una especie botánica del género Rhus", refiriéndose al nombre vulgar del Rhus vernicífera, conocido también como árbol urushi, árbol de cuya savia se extrae la goma empleada para la realización de la laca. Existe también un falso zumaque que se obtiene del Ailanthus altísima, conocido como "barniz del Japón", "falso barniz", “árbol del cielo" y "árbol de los dioses"13.

El género botánico Rhus, con unas 250 especies, incluye un tipo de arbusto de la familia de las Anacardiaceas, estudiadas por Hendrick (1972: 314), del que existen cuatro variedades relacionadas con la presente investigación. El Rhus typhina, conocido comúnmente como zumaque de Virginia, es un arbusto de cinco o seis metros de altura que segrega una savia o resina empleada en la realización de las lacas (Beck 2007: 66-67). El Rhus coriaria, conocido vulgarmente como zumaque, produce un tipo de fruto que, molido, se emplea para curtir cueros por su alto contenido en taninos (13\% al 28\%) que hace al cuero más resistente a la luz, debido a las propiedades antioxidantes del ácido gálico que también posee. En ocasiones también se emplea la savia para fijar diversos colores al cuero por sus cualidades mordentes o adhesivas. El Rhus muelleri, conocido como zumac de Müller, es un tipo de arbusto siempre verde, endémico de México, que se encuentra en la Sierra Madre Oriental y en el Altiplano, en zonas boscosas de pinos y encinos. El Rhus oaxacana, conocido también como zumaque, es un arbusto endémico oaxaqueño que crece de forma espontánea o salvaje en las sierras de la región ${ }^{14}$.

Esta investigación ha constatado, por primera vez, a través de los análisis realizados por la Dra. Alejandra Quintanar (UANM), el empleo de madera de Rhus oaxacana o zumaque en estos muebles oaxaqueños, con lo que el término "zumaque", tradicionalmente empleado sin una justificación precisa, tiene una ahora una acepción clara y concreta en estas producciones. Es posible que en la pasta de los rellenos decorativos se emplee también la savia, utilizada en Japón para la elaboración de lacas y en Oaxaca para fijar colores, por sus cualidades adhesivas y mordente. Pudiendo intervenir también en la pasta las semillas, las molidas, por sus particulares antioxidantes. Si se confirmara, mediante el análisis químico, la presencia

\footnotetext{
${ }^{13}$ Nombres populares empleados comúnmente tomados de Internet .infojardin.com/ arboles/ailanthus-altissima-ailanto-arbol-cielo.htm -www.botanicoatlantico.org/.../ailantoarbol-de-los-dioses-arbol-del-cielo.es.wikipedia.org/wiki/Ailanthus_altissima

${ }^{14}$ En los trabajos de campo realizados, en 2010, en la zona montañosa limítrofe a Villa Alta se constató la presencia de abundantes arbustos de zumaque que fueron mostrados y muestreados por los pobladores, quienes conocían sus diversos usos, entre ellos la aplicación en el mobiliario, mientras que las poblaciones cercanas, a unos diez kilómetros, carecen de ellos, desconociendo sus habitantes su presencia.
} 
de estos dos productos del Rhus en la pasta, esta también podría nombrarse zumaque como tradicionalmente se viene haciendo ${ }^{15}$.

Rodríguez (2006: 689), al referirse al zumaque, lo relaciona con el empleo de madera proveniente del Rhus coriaria, europeo. Al describir sus características, destaca su color amarillo con vetas verdosas, comentando que se empleó en trabajos de ebanistería francesa e italiana desde el siglo XVIII, siendo conocida también como Madera de Hungría. En el caso de los muebles novohispanos se emplea la madera de este género pero de una especie endémica y particular de la región oaxaqueña con vetas color castaño.

Si bien es cierto que el origen de estos muebles zumacados se circunscribe a la región oaxaqueña (Romero de Terreros 1982: 253), antiguamente llamada Antequera, estas producciones están estrechamente ligadas a la localidad de Villa Alta de San Ildefonso ${ }^{16}$ o Villalta, en la Mixteca Alta, como han señalado Armella (1994: 17) y Curiel (2003: 137; 2006: 344). San Ildefonso de Villa Alta, fundado el 25 de enero de 1526, fue un gran centro productor de grana cochinilla durante el Virreinato ${ }^{17}$. Sus trabajos característicos están

${ }^{15}$ Actualmente, la Universidad Autónoma Metropolitana, en México, y la Universidad Politécnica de Valencia, en España, analizan en sus laboratorios de química y física los componentes de la pasta de estos muebles para poder definirlos con precisión y así saber cómo está elaborada. Los primeros análisis realizados con las técnicas instrumentales de Espectroscopia Infrarroja por Transformada de Fourier (FTIR) y Pirólisis-Cromatografía de Gases-Espectrometría de masas (Py-GC-MS) confirman que las sustancias que intervienen en su composición son de tipo glicérico, polisacáridos, céridos, oxalatos de calcio, resinas y sales cálcicas. Es necesario ahora muestrear en el campo los posibles materiales empleados para comparar los resultados y poder determinar los componentes con precisión.

16 Situada al noreste de estado de Oaxaca a 1,750 msnm, la separa de los valles de Oaxaca una cadena montañosa conocida como Sierra Zapoteca. Su fundación realizada en 1526 por Diego de Figueroa fue motivada por la avanzada militar española, para contener los ataques indígenas de la sierra. Al adquirir el rango de villa se convirtió en cabecera de alcaldía mayor, sede de cabildo y morada de religiosos dominicos. Fue la quinta receptoría en importancia de las ocho que existían en la Intendencia de Oaxaca y era un punto importante dentro de las rutas comerciales de la región. Su aislada situación geográfica permitió que, además de ser estratégico enclave militar, cubriera como cabecera de distrito a más de cincuenta poblaciones cercanas. Todo ello la convirtió en un importante núcleo mercantil en el que se comercializaba principalmente grana $\mathrm{CO}^{-}$ chinilla y tejidos de algodón.

${ }^{17}$ Hacia 1600 pasó a ser una de las villas más codiciadas por los comerciantes y Alcaldes Mayores, dada su excepcional capacidad para producir estas mercancías, y por la calidad de las mismas. Se puede decir que el siglo XVIII fue su "época dorada" por su floreciente mercado y la demanda internacional que tuvo del tinte cochinilla, que era exportado a España, Francia, Holanda e Inglaterra. Al paso del tiempo, diversas epidemias disminuyeron a la población indígena que se encargaba del cultivo de la grana, 
relacionados con los textiles ${ }^{18}$, la talabartería ${ }^{19}$ y la producción de mobiliario. Estos últimos son citados, en múltiples ocasiones, en inventarios y testamentarías consultados, ejemplificando las tipologías más características, como sucede en el del Alférez Nicolás Oñes de Gamboa (1683: Leg, 4, exp. 14, foja 20) en el que se describen dos cajas taraceadas, obra de Villa Alta. En el de Juan Martín de Villalonga (1682: Leg. 4, exp. 2, foja 10) se citan dos baúles taraceados, obra de Villa Alta, en el de Pedro Canon de Amaya (1687: Lej. 7, exp. 4, foja 15) se cita un escritorio obra de Villa Alta, así como en el de Alonso Sarmiento de Sebreros (1712: Leg. 13, exp. 22, foja 19), dos escritorios grandes y otros dos pequeños, obra de Villa Alta y en el de Bartolomé Groso (1726: Leg. 14, exp. 14, foja 12), una papelera, obra de Villa Alta. Estos datos corroboran que Villa Alta fue un centro productor de muebles, muy renombrado en la región, durante el Virreinato ${ }^{20}$, aunque no se detalla la técnica decorativa empleada en su ejecución, a excepción del término taraceado que figura en alguno de los documentos citados.

El único mueble estudiado que permite asegurar fehacientemente el origen de estas piezas se encuentra en la colección Carlton Hobbs en Nueva York (fig. 5).

Este escritorio del siglo XVII, además de poseer magnífica calidad técnica, iconográficamente es de gran exhuberancia, dándonos las pruebas de su origen en los motivos decorativos externos. En la tapa central se representa el plano de la Villa Alta de San Ildefonso con la leyenda "MAPA D LA VI ALTA DE SILLEFONSO” (Fig. 6), mientras que en el interior aparecen las

con lo que dio inicio la decadencia productiva de la afamada tintura. Otros factores que incidieron en el colapso de su producción fueron la competencia que se estableció con Guatemala y el surgimiento de los tintes químicos. Durante la Guerra de Independencia el negocio textil floreció nuevamente en la región, entre otras cosas porque las tropas insurgentes vestían uniformes de algodón, confeccionados en Villa Alta. Hoy por hoy, el difícil acceso a Villa Alta y su mermada población laboral motivada por la emigración y la falta de producciones comerciales, ha llevado al olvido a este importante centro productor de muebles marqueteados, de cuya activad se conoce muy poco.

${ }^{18}$ En el Inventario de los bienes del Teniente Coronel de Infantería D. Joseph Mariano Martínez (1766: Leg. 34, exp. 8, foja, 28), se señalan diez y seis mantas de Villa Alta. Para completar esta información véase la Carta del administrador de alcabalas de Villa Alta a la Dirección de Alcabalas, 30 de abril de 1804. Archivo General de la Nación, México, Alcabalas, caja 1192.

${ }^{19}$ En la zona, son muy comunes los arbustos salvajes de zumaque, del que se aprovechaban los frutos y la savia en las labores de talabartería. Esta abundancia de zumaque posibilitó el empleo de su madera en el revestimiento de los muebles estudiados.

${ }^{20}$ Es interesante apreciar cómo en ninguno de los documentos consultados figuran piezas de mobiliario, decoradas con zumaque, diferentes a las conservadas y a las descritas con anterioridad. 
cuatro estaciones rodeando al sol (Fig. 7). En los laterales figuran el Barrio de Analco "BARRIO DANALCO" (Fig. 8) y el Salto del Agua "SALTO DAGUA" (Fig. 9) ubicados en la localidad.

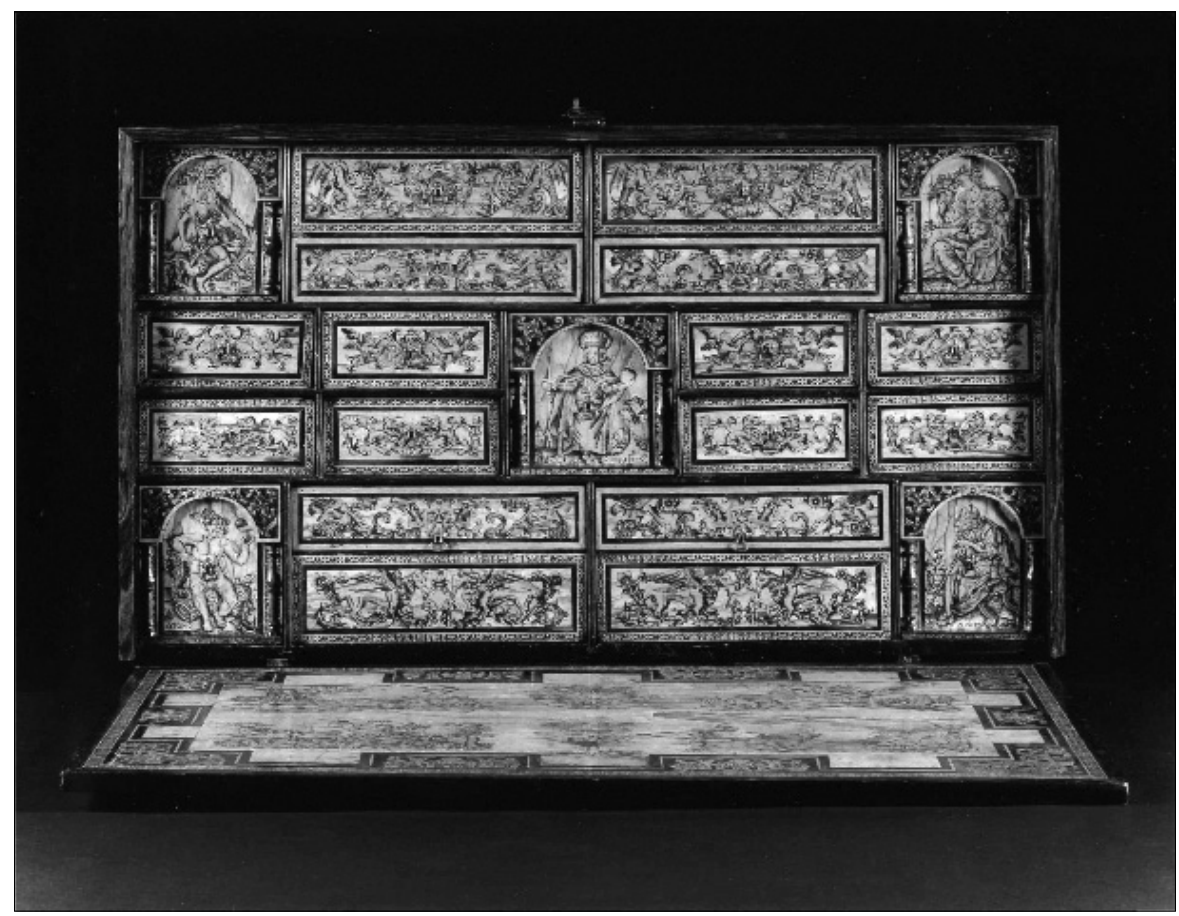

FIGURA 5. Escritorio oaxaqueño abierto, decoración en zumaque, siglo XVII. Colección Carlton Hobbs, Nueva York.

${ }^{21}$ Este barrio, situado al oeste de la Villa, era eminentemente indígena (tlaxcaltecos) estando gobernado por un cuerpo de principales; albergaba una "Casa de República", una ermita dedicada a la Virgen de la Asunción y varios caseríos indígenas, según describe el Testimonio sobre la compra de una casa en Villa Alta por Don Pedro de Ortega (1786-1790), AGNM, vol. 30, exp. 1, ff. 1-5v. El que fueran indígenas tlaxcaltecos los habitantes del Barrio de Analco, puede relacionarse con algunas crónicas, siglo XVI, sobre la llegada de los españoles a Cholula, población Tlaxcalteca en la época prehispánica, en las que relatan cómo, los pobladores nativos de estas tierras sacrifican niños al dios Quetzalcohuatl, para evitar desbordamiento e inundaciones, mezclando su sangre con cal, a manera de zulaque, para tapar los manantiales y las fuentes (Muñoz Camargo 2000: Lib. II, cap. V). 


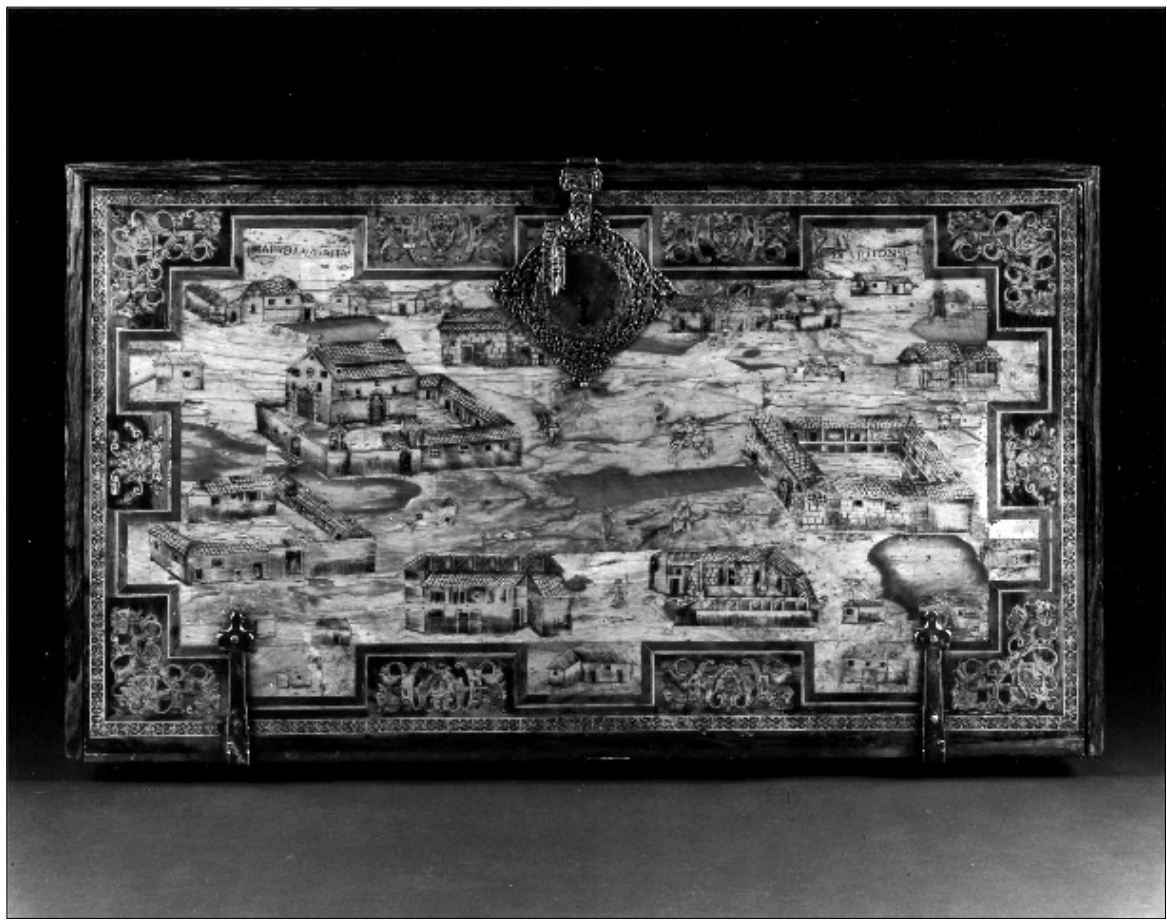

Figura 6. Detalle exterior de la tapa frontal abatible donde se representa el plano de Villa Alta de San Ildefonso, Oaxaca. Escritorio oaxaqueño, decoración en zumaque, siglo XVII. Colección Carlton Hobbs, Nueva York.

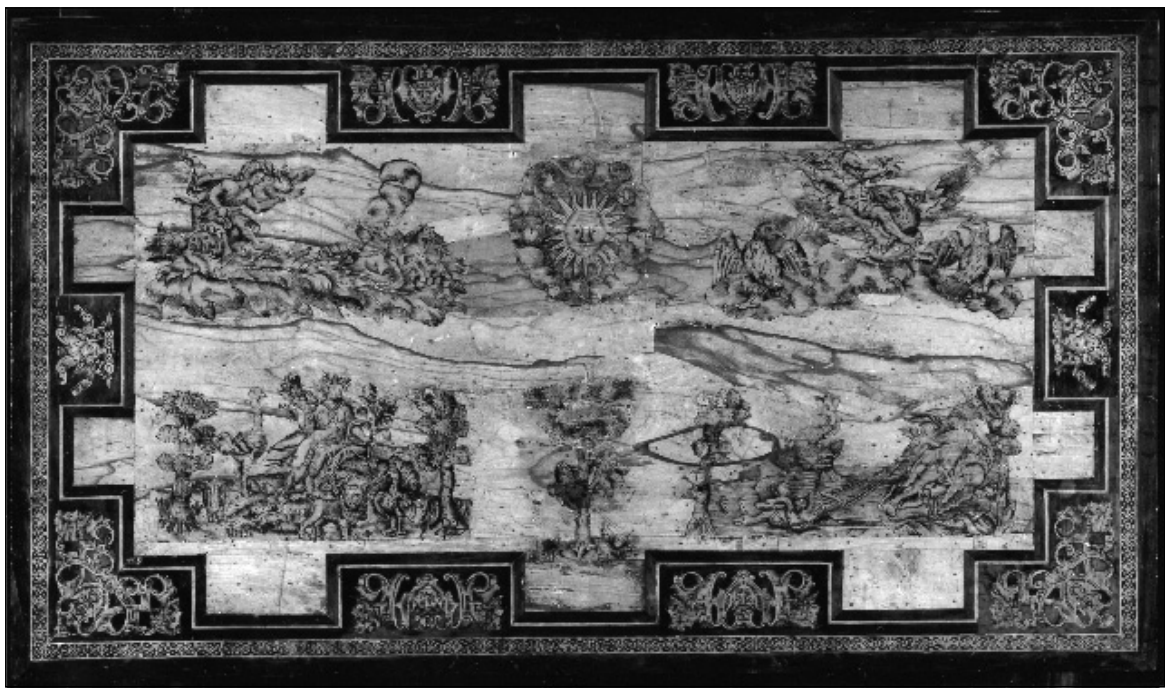

FIGURA 7. Detalle interior de la tapa frontal abatible donde se representan las cuatro estaciones y el sol. Escritorio oaxaqueño, decoración en zumaque, siglo XVII. Colección Carlton Hobbs, Nueva York. 


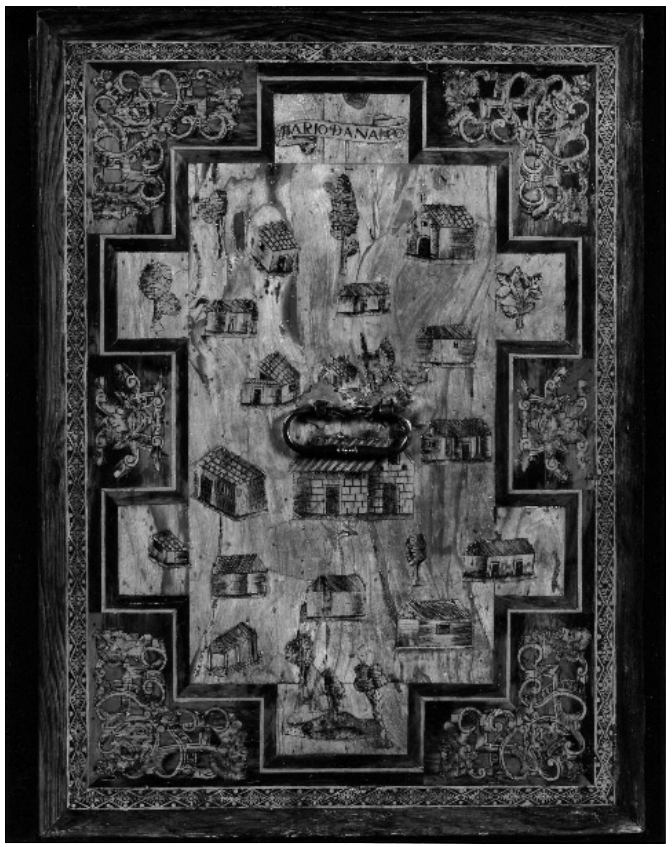

Figura 8. Detalle exterior del costado derecho donde se representa el Barrio de Analco, en Villa Alta de San Ildefonso, Oaxaca. Escritorio oaxaqueño, decoración en zumaque, siglo XVII. Colección Carlton Hobbs, Nueva York.

Figura 9. Detalle exterior del costado izquierdo donde se representa el Salto del Agua, en Villa Alta de San Ildefonso, Oaxaca. Escritorio oaxaqueño, decoración en zumaque, siglo xviI. Colección Carlton Hobbs, Nueva York.

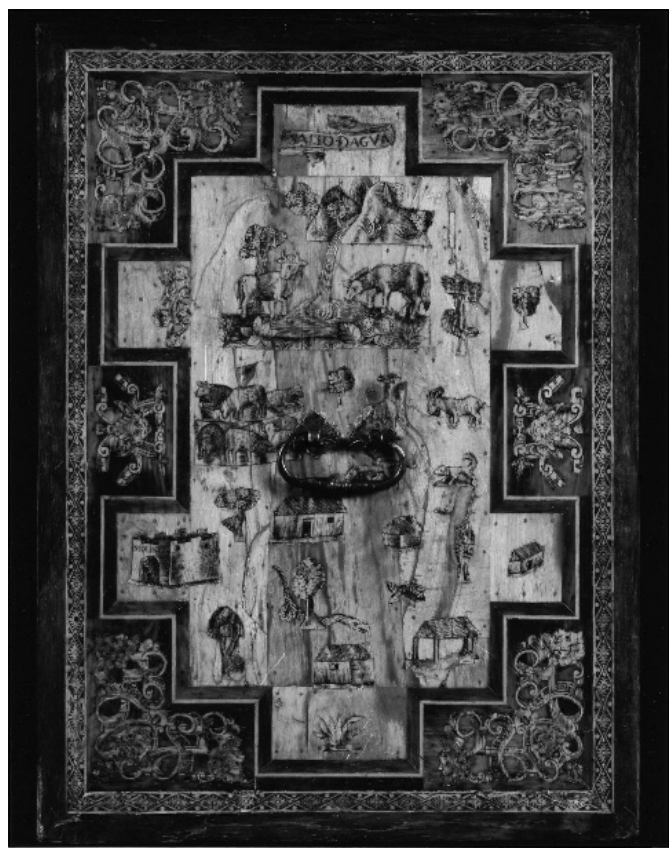




\section{LAS MADERAS}

Los muebles zumacados suelen estar construidos con maderas comunes y poco llamativas de la familia Pinaceae del género Pinus, esto es, pino común, (Cronquist 1981: 33) y de la familia Meliaceae, del género Cederla como el cedro rojo, abundante en la sierra oaxaqueña (Arce 2001: 33-34).

Esta estructura o alma, realizada en maderas poco costosas, sin valor estético, se recubre y oculta, interior ${ }^{22}$ y exteriormente, con finas chapas y reengruesos de zumaque (Fig. 10), Rhus, arbusto de la familia de las Anacardiaceas, del género Rhus, con reducido diámetro, en tronco y ramas, pegadas mediante adhesivos o colas naturales ${ }^{23}$. Para reforzar la cohesión entre las chapas y el alma se emplean pequeños taquetillos o toretillos de madera. Entre sus características macroscópicas ${ }^{24}$, destaca el color crema con vetas irregulares en tono castaño oscuro, por lo que se emplean cortes tangenciales para aprovechar sus contrastes cromáticos ${ }^{25}$.

Por lo regular, en las decoraciones chapeadas exteriores, son las chapas de maderas claras, más delicadas, las que presentan mayor número de taquetes (Fig. 11), debido a la pérdida de rigidez que motivan los recortes y los trabajos incisos.

En las chapas oscuras también es palpable la presencia de taquetes aunque en menor número ${ }^{26}$. La utilización de estos taquetillos es frecuente en las piezas más antiguas, realizadas en el siglo XVII, mientras que en las dieciochescas casi no están presentes, lo que nos indica que en esta centu-

${ }^{22}$ No en todos los muebles estudiados, los interiores están recubiertos de chapas, en algunos, los poco costosos, los interiores muestran la madera secundaria con la que están construidos.

${ }^{23}$ Hobbs (1943: 33-45), en su tratado sobre el enchapado, describe en detalle los procedimientos empleados para la fijación de las chapas, haciendo hincapié en los adhesivos más empleados.

${ }^{24}$ No presentan albura y duramen definidos. Las zonas de crecimiento son visibles a simple vista, marcadas por parénquima marginal y una serie de poros describiendo una tendencia semicircular. El parénquima axial es visible con aumento de 10x. La textura es de fina a mediana, el hilo es entrecruzado con olor y sabor no característicos.

${ }^{25}$ En ninguno de los muebles estudiados por la Dra. Quintanar se ha detectado el uso de cortes radiales.

${ }^{26}$ Ya que los motivos decorativos, sobre madera clara de zumaque están incluidos en chapas más oscuras, más resistente, a modo de la técnica parte y contra parte empleada en Francia, por André Charles Boulle en las decoraciones de carey y bronce. Véanse a detalle las esquinas del escritorio de la colección Cartlon Hobbs LLC. 


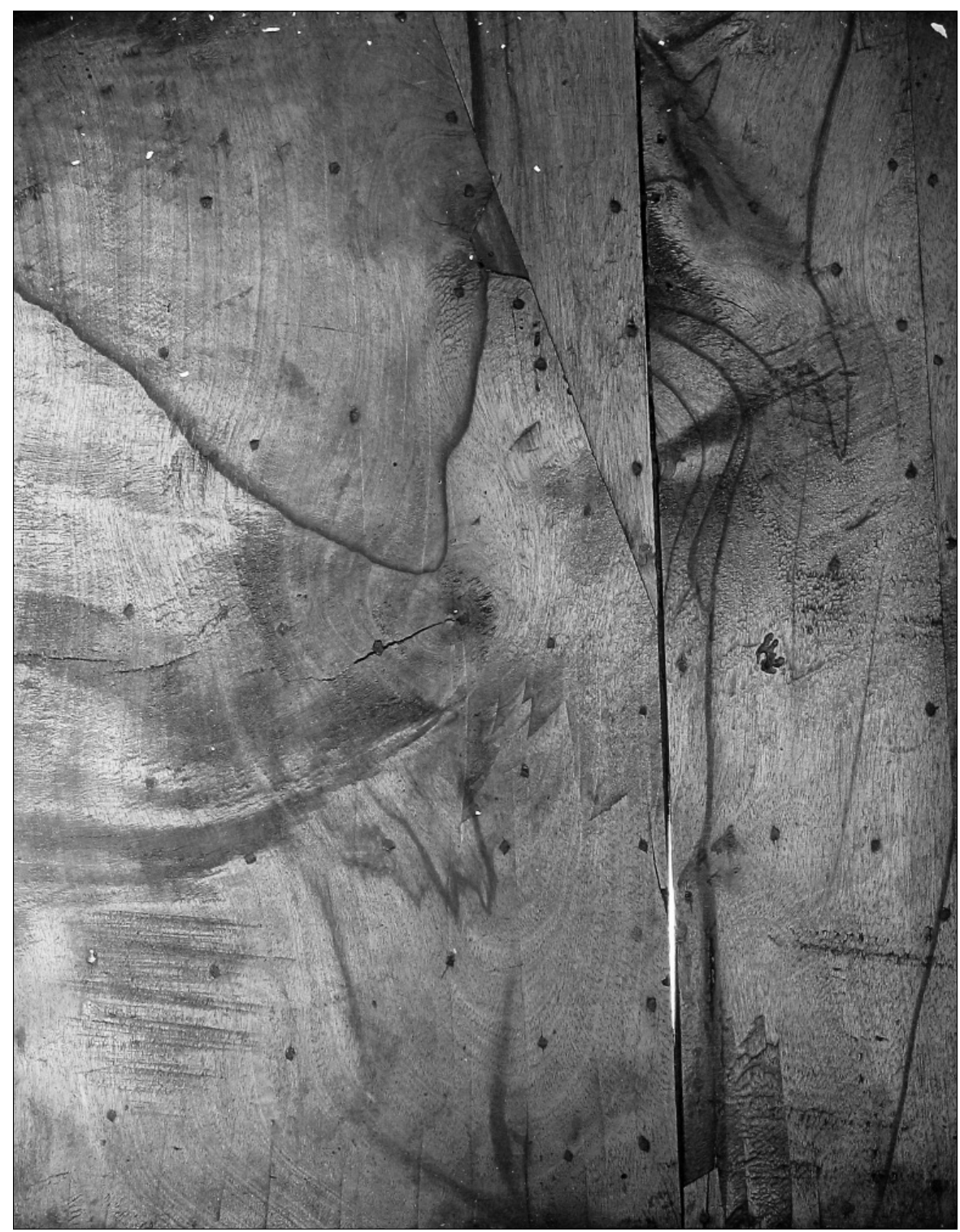

FIGURA 10. Detalle, interior de escritorio oaxaqueño, decoración en zumaque, siglo XVII. Museo Nacional de Artes Decorativas, Madrid. 


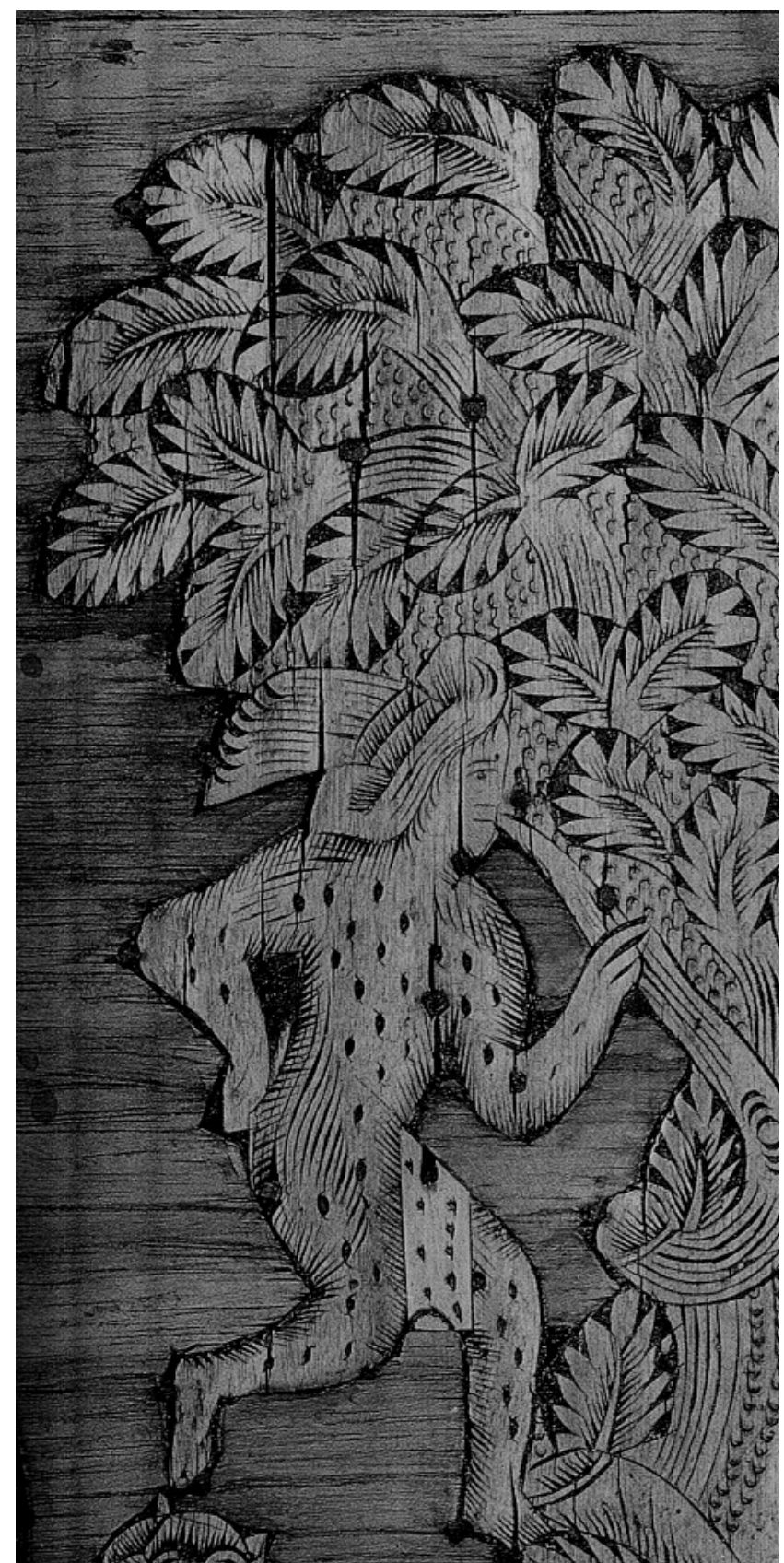

FIGURA 11. Detalle, escritorio oaxaqueño, decoración en zumaque, siglo XVII. Colección particular, México. 
ria contaban con mayores avances técnicos. En raros ejemplares encontramos los interiores decorados con incisiones rellenas de pasta ${ }^{27}$.

Las chapas oscuras y veteadas, que aparecen como fondo de la decoración marqueteada, suelen provenir de maderas de la familia Leguminosae, analizadas por Lewis (2005: 57), del género Lonchocarpus o machiche y del género Platymiscium o granadillo y en ocasiones se han detectado chapas del género Dalbergia o palosanto.

Las chapas claras, como se ha dicho, provienen de arbustos de Rhus o zumaque y de árboles de la familia Meliaceae, de los géneros Swietenia y Melia, conocidos como caoba o caobilla. De la familia de Leguninosae, se emplea la Acacia mexicana (Rico 2005: 89-92) y de la familia Lauraceae, del género Phoebe, el aguacatillo, analizadas en México por Lorea-Hernández (2005: 61-87). Por lo regular, son las chapas más claras las que presentan decoraciones incisas y rellenas, manteniéndose en contraste con las chapas de madera oscura sin $\operatorname{trabajar}^{28}$.

\section{LA TÉCNICA DEL ZUMAQUE}

Una vez construido el mueble, se procede a seleccionar las chapas de las diversas maderas según la composición cromática determinada previamente, se traza el diseño decorativo, presumiblemente, mediante plantillas de papel. Diseño recortado que recuerda, en cierta medida, los famosos trabajos mexicanos de los papeles picados, de gran tradición en la zona oaxaqueña, empleados en la decoración efímera de festividades, tanto civiles como religiosas, para engalanar calles, iglesias, altares y casas.

Es habitual, sobre todo en las obras más tempranas, que las chapas recortadas de madera clara no encajen a la perfección con las oscuras; esto motiva, en los diseños más complicados, la aplicación de pequeñas piezas oscuras entre los contornos claros con un abundante relleno de pasta en las oquedades, logrando limitar con mayor fuerza los contornos y las formas de los motivos decorativos.

${ }^{27}$ Como las del escritorillo de la colección Colegio de San Ignacio de Loyola (Las Vizcaínas), México.

${ }^{28} \mathrm{El}$ estudio de estas maderas, muestreando unas quince piezas decoradas con zumaque pertenecientes al Museo Franz Mayer, ha sido realizado por la Dra. Alejandra Quintanar, asistida por Mariana Castillo. De esta investigación se destaca, además de la identificación de las maderas, la presencia de este tipo de especies botánicas en la foresta oaxaqueña, lo que nos indica que los maestros en la técnica empleaban árboles propios de la región, para los trabajos en zumaque y algunas otras maderas foráneas llegaban a la zona a través de las rutas comerciales. 
En casos excepcionales, ya mencionados, la decoración es aplicada sobre las chapas de madera oscuras mientras las claras, sin decorar, actúan como fondo de la decoración ${ }^{29}$ (Fig. 12).

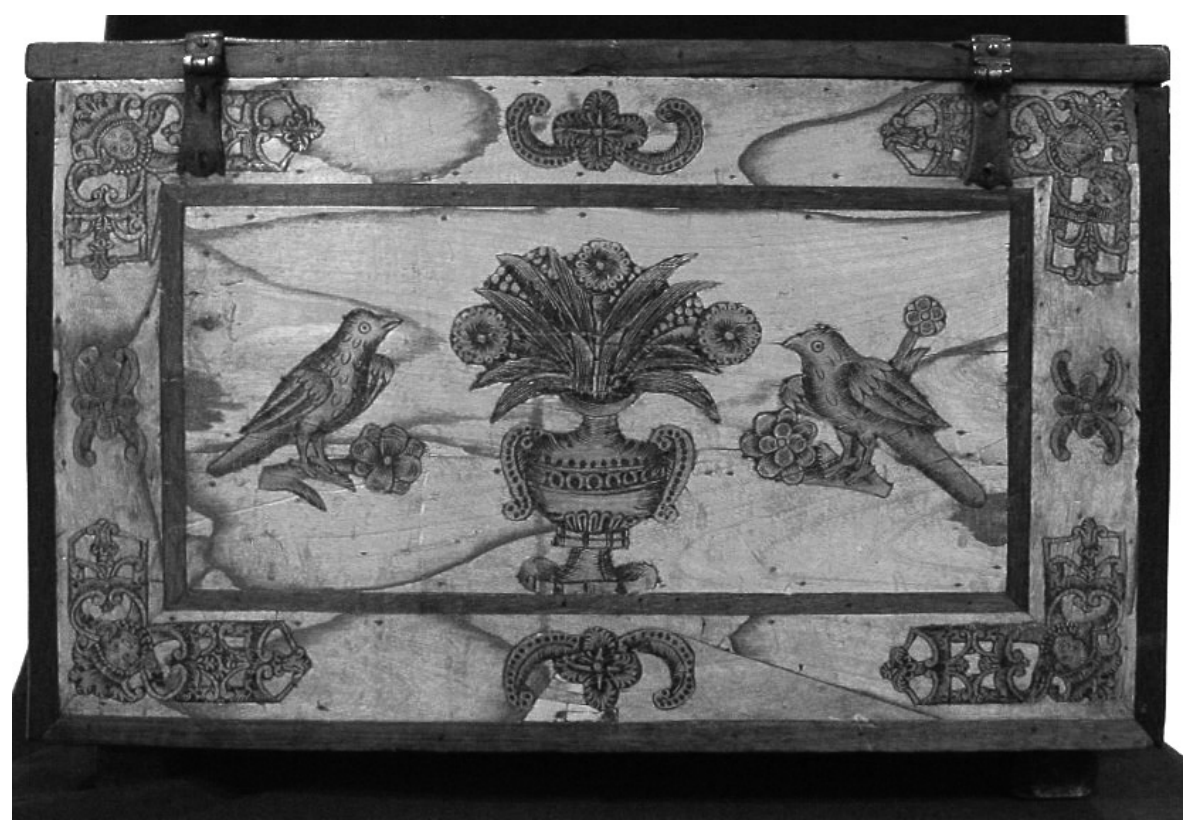

FIGURA 12. Escritorillo oaxaqueño, decoración en zumaque, siglo XVII. Museo Franz Mayer, México. (CCB-0019).

Las incisiones de los motivos decorativos pueden relacionarse, dada la similitud de trazos que forman los diseños, con la técnica de grabado sobre lámina de cobre y con la xilografía o grabado en madera ampliamente difundidos, ya que emplean materiales y herramientas similares, con resultados contrastados muy parecidos. Generalmente, la pasta resalta los motivos decorativos en negro aunque algunos ejemplares de gran calidad, sobre todo los realizados en el siglo XVII, presentan diversas tonalidades combinadas como el verde y el rojo. En raros casos algunas tonalidades son aplicaciones mediante pincel sobre la madera y la pasta.

29 De igual manera, en algunas de las piezas estudiadas se observa la ausencia de madera de zumaque siendo esta reemplazada por otras maderas claras similares como el limoncillo, endémico de la región, sobre la que se realiza la misma técnica decorativa. Esto podría obedecer a carencias en la producción forestal de la zona o a encargos particulares. 
Llama la atención que no existan en el mercado del arte y en los trabajos artesanales reproducciones de piezas decoradas en zumaque ni obras originales posteriores al último cuarto del siglo XIX. Ello nos indica que el o los talleres zumaqueros, al cerrar sus puertas en el siglo XIX, sin un motivo conocido aun ${ }^{30}$, no continuaron con este rico arte y los maestros no pudieron transmitir sus conocimientos a generaciones futuras.

\section{PARTICULARIDADES CONSTRUCTIVAS DE LOS MUEBLES ZUMACADOS}

Los escritorios, papeleras y arquillas novohispanos decorados y realizados con zumaque reúnen ciertas particularidades constructivas que los diferencian de los realizados en otras regiones del contexto hispánico. Todos ellos siguen el esquema constructivo de caja prismática, abierta o cerrada según los casos, en la que los laterales se unen mediante ensambladuras de lazos de cola de milano vista o almenada con la solera o fondo (Fig. 13) y la parte superior ${ }^{31}$.

Las traseras, por lo regular cuidadas pero no para ser vistas, dado que las piezas estaban arrimadas a la pared, se ensamblan con colas de milano o almenada y a tope con clavos de hierro forjado o taquetes de madera sobre los cantos de los anteriores. En algunos ejemplares las traseras se unen a media madera sobre los laterales, por lo común en aquellas piezas en las que la decoración abarca la parte trasera de los escritorillos, arquillas y baulillos de estrado, lo que permitiría una visión circular. Las ensambladuras suelen carecer de escuadras y ángulos en hierro que las refuercen; algunos han sido colocados posteriormente, como trabajo de anticuario.

Los herrajes realizados en hierro forjado, recortado, calado y biselado, habitualmente dorados, casi nunca eran colocados en Nueva España sobre terciopelo. Los herrajes se emplean únicamente en asas bisagras extendidas, cerraduras, cerrajillas, fallebas, palastros y tiradores (Fig. 14), siguiendo diseños y formas europeas pero con un tratamiento propio de la metalurgia novohispana que corrobora el mestizaje cultural ${ }^{32}$.

\footnotetext{
${ }^{30}$ Pero en el que presumiblemente influyeron la caída de las producciones comerciales de grana y de textiles, las diversas epidemias de sus habitantes, el olvido de las rutas comerciales virreinales tras la consumación de la Independencia de México en 1821, los movimientos prerrevolucionarios, la emigración de sus pobladores y la deforestación de la zona.

${ }^{31}$ Sistema constructivo empleado también en los baúles, arquetas y baulillos zumacados.

${ }^{32}$ En los Cuadernos de viento (registran las mercancías cuyo valor fuera inferior a 10 pesos, que entraban semanalmente en Villa Alta) y los Libros reales (aquellos que ano-
} 


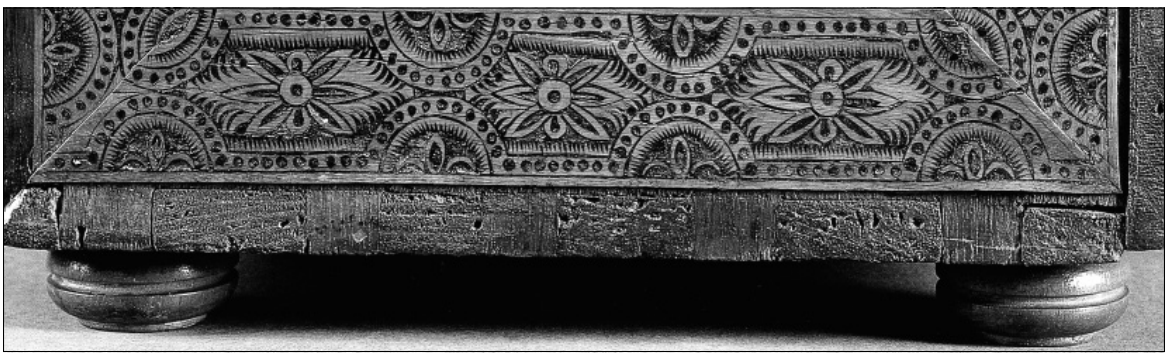

FIGURA 13. Detalle, escritorio oaxaqueño, decoración en zumaque, siglo XVII. Museo Nacional de Artes Decorativas, Madrid. Cat. 3124.

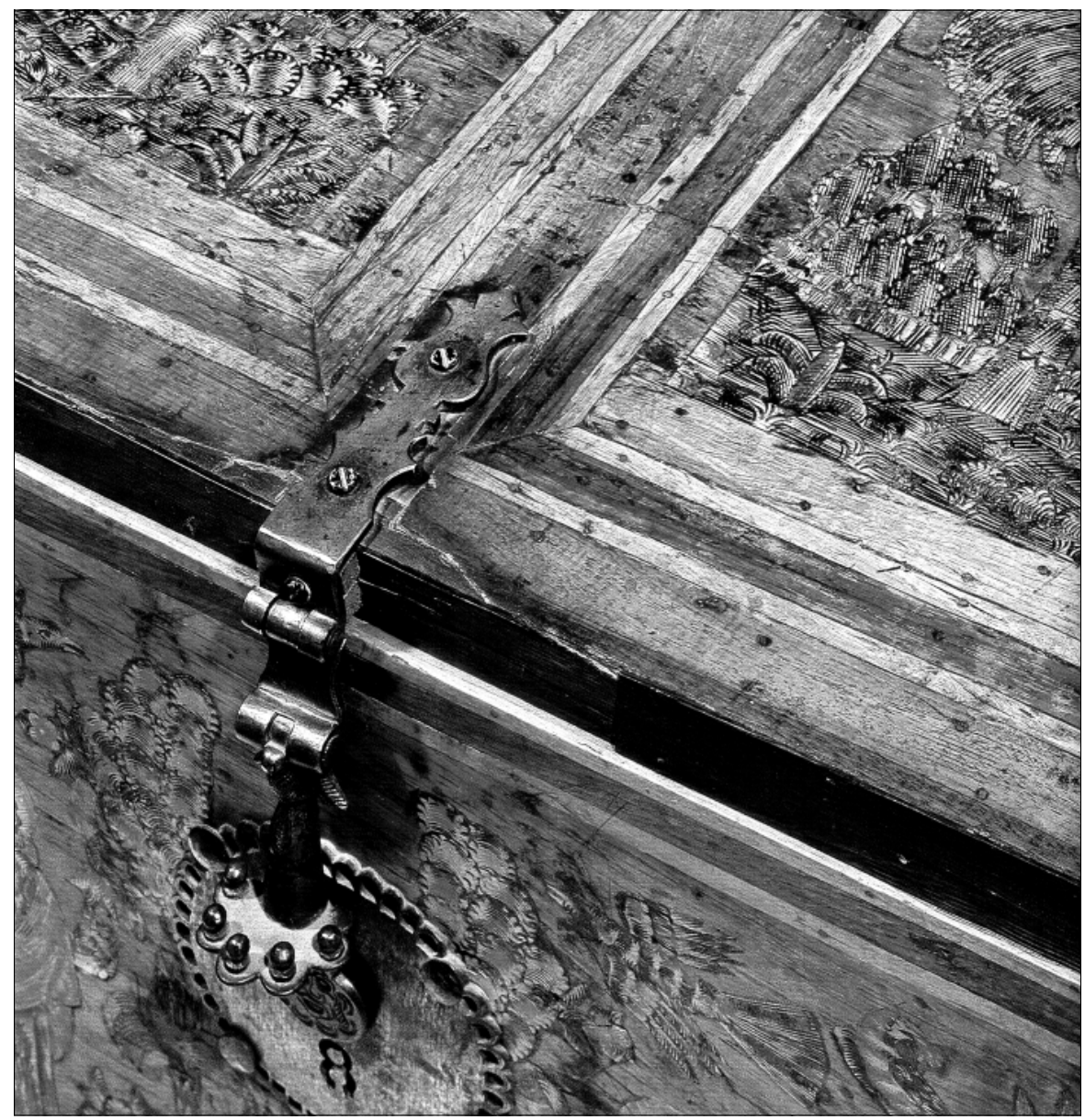

FIGURA 14. Detalle de palastro y cerradura, escritorillo oaxaqueño, decoración en zumaque siglo XVII. Colección particular, México. 
La compartimentación interior o muestra, constructivamente mantiene esquemas compositivos muy similares a los de los ejemplares llegados de ultramar, predominando el estilo misional (Aguiló 1990: 120), en el que una puerta o gaveta central, a modo de nicho, incluye una imagen religiosa, vinculada con la devoción del propietario, rodeada de gavetas $^{33}$ (Fig. 15).

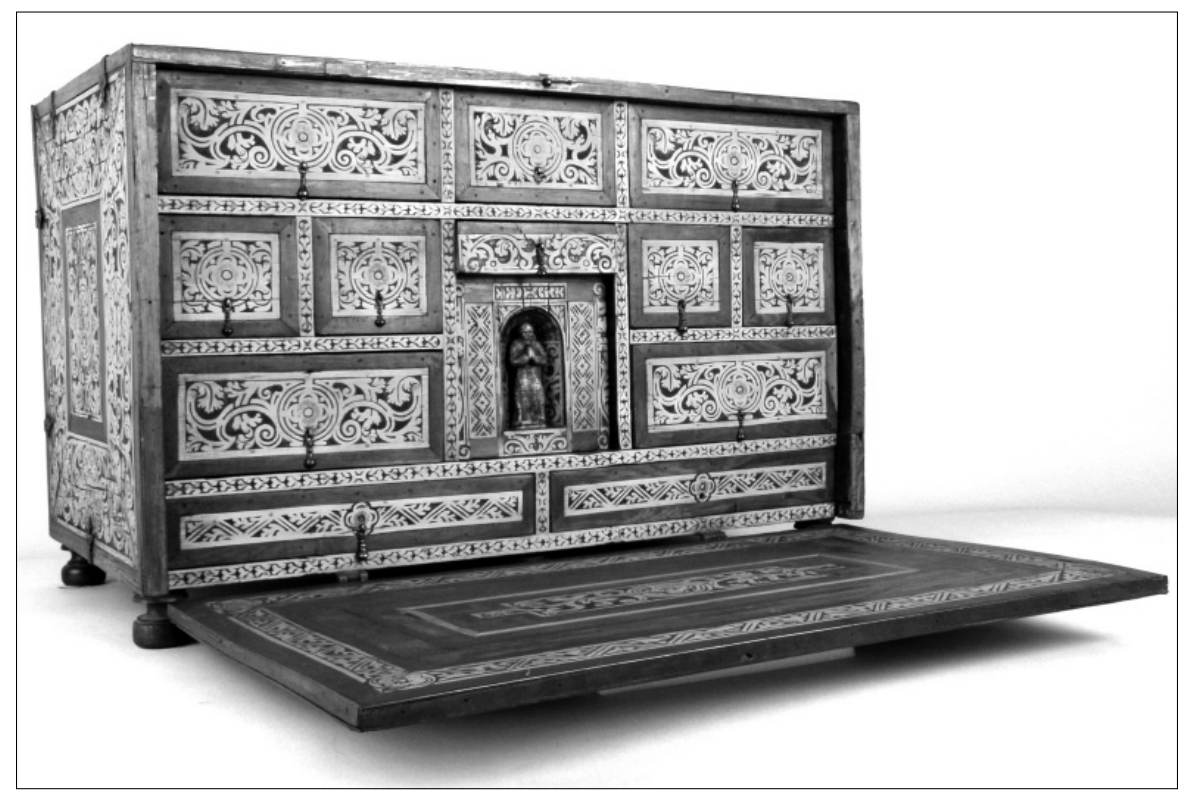

FIgURA 15. Escritorillo oaxaqueño, decoración en zumaque, siglo XVIII. Museo Franz Mayer, México. (CBD-0030).

Es inusual el empleo de puertas laterales y las centrales suelen ser gavetas simulando puertas aunque en raros casos sí se muestran como tales, como se puede apreciar en el escritorillo de la colección Josephus Daniels (Fig. 16), publicado por Shorto (1996: 102-103).

Llama la atención en las piezas novohispanas que los atajos, compuestos por tabicas verticales y entrepaños horizontales, están realizados a media madera, es decir, no llegan al fondo del mueble o a tres cuartos del

tan las operaciones cuyos montos fueran superiores a 10 pesos), figuran como efectos de Castilla mercancías tales como herrajes y barras de hierro. Véase los Cuadernos de viento correspondientes a: 1791, 1792, 1793 y 1794, y los Libros reales de 1790 y 1795 del Archivo General de la Nación, México.

${ }^{33}$ En los escritorios, papeleras y escritorillos estudiados llama la atención la ausencia de gavetas ocultas o compartimentos secretos al interior de la muestra. 


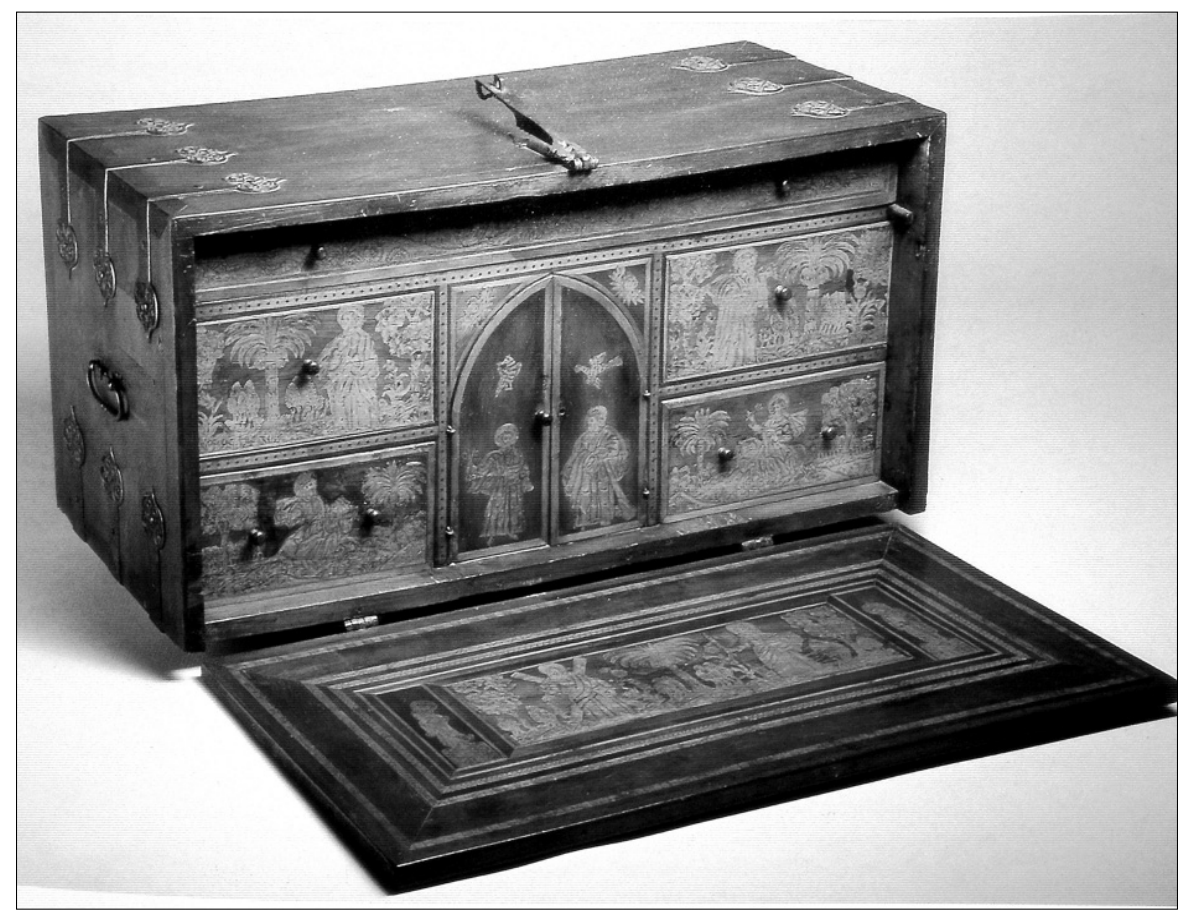

FIGURA 16. Escritorillo oaxaqueño, decoración en zumaque, siglo XVIII. Colección Josephus Daniels, Estados Unidos de Norteamérica.

mismo, como sucede en los escritorios europeos y españoles de calidad media. Por el contrario, abarcan la mitad del espacio interior y dejan libre la otra mitad (Fig. 17).

En otros casos hemos constatado el empleo de guías o listones de madera ensamblados a las tabicas y a los entrepaños para detener las gavetas. Esta particularidad puede obedecer a un ahorro de madera en aquellas partes no visibles y apoya la teoría de que los carpinteros novohispanos no pudieron analizar en profundidad las características constructivas internas de las obras foráneas. Los atajos se ensamblan entre sí a tope o en cuña, reforzados con toretes ocultos bajo la decoración enchapada, Por lo regular las calles suelen ser más anchas que los registros en las piezas de gran formato.

En cuanto a las arcas y baúles decorados mediante zumaque ${ }^{34}$, siguen los modelos constructivos españoles, con diversas tipologías según el tama-

${ }^{34}$ Uno de los más bellos ejemplares participó en la exposición Oro y plata de las Indias en la época de los Austrias, Meleón (1990: 111). Esta importante pieza se encontraba en Italia, fue adquirida por un anticuario mexicano y ahora se encuentra en una colección particular en México. 


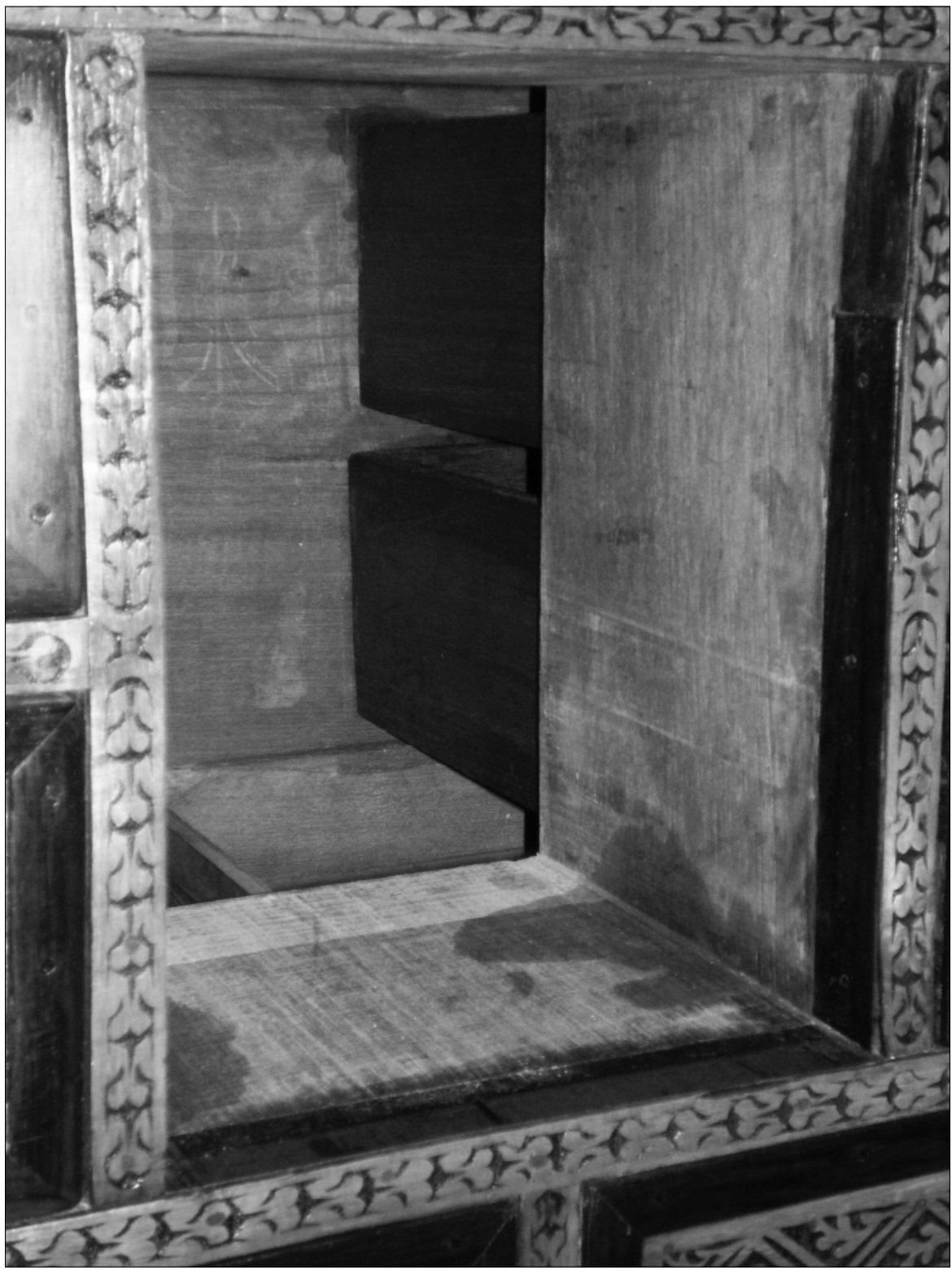

FIGURA 17. Detalle interior, escritorio oaxaqueño, decoración en zumaque, siglo XVIII. Museo Franz Mayer, México. (CBD-0030). 
ño y la forma, siendo una característica particular novohispana que los interiores estén enchapados de pedacería diversa de zumaque. Entre las de gran tamaño, algunas conservan los pies o zancos a juego (Fig. 18), para evitar que la humedad del suelo afecte el contenido.

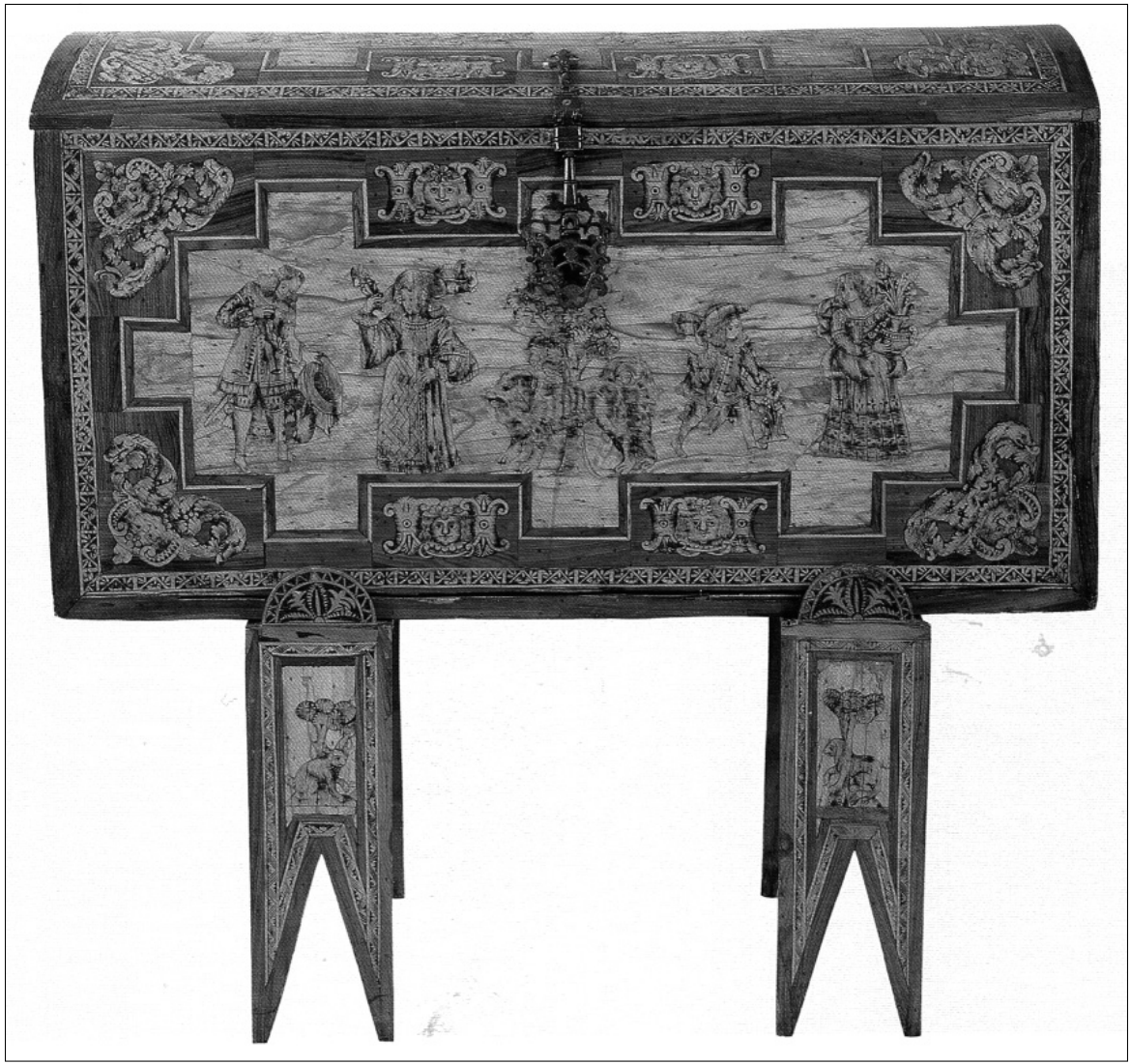

Figura 18. Baúl con zancos oaxaqueño, decoración en zumaque, siglo XVII, Museo Nacional de Artes Decorativas, Madrid.

La decoración empleada en todas las piezas zumacadas es de una amplia variedad, abarcando desde los temas emblemáticos hasta los motivos religiosos, pasando por la heráldica y las escenas costumbristas, los animales y las plantas. En las cenefas se emplean diseños muy variados, geométricos, florales y combinados, algunos tomados de los motivos decorativos prehispánicos (Mitla en Oaxaca) y otros de grabados. La diversidad de los temas 
requeriría un artículo especial. Solamente mencionaremos el importante papel que desempeñó el grabado en la difusión de motivos decorativos convertidos en el medio común para la divulgación, tanto de estilos artísticos como de modelos a seguir en los lejanos territorios de la monarquía hispánica (Corrales 1998, 2000). A ello puede sumarse la influencia que ejercieron los libros impresos y los libros de coro bellamente ilustrados (Checa 1988). Esta afluencia de modelos popularizará los motivos más aceptados por la clientela que encargaba las piezas zumacadas. Un estudio profundo de los motivos decorativos que se está realizando, podrá abrir nuevas vías de investigación sobre los talleres que realizaron estas piezas en épocas pretéritas.

A manera de conclusión y una vez analizadas las piezas conservadas, las terminologías empleadas en diversas épocas, las maderas y las técnicas constructivas y decorativas de estos singulares muebles, sería conveniente agruparlos bajo único término general "La Marquetería de Villa Alta", resumiendo en él las particularidades de esta sublime y olvidada producción virreinal novohispana en la que interviene, generalmente en chapas y reengruesos, la madera de zumaque junto a otras para conformar llamativos mosaicos sobre los que se aplica la decoración esgrafiada y rellena de pasta.

\section{BIBLIOGRAFÍA CITADA}

Aguiló, M. P. 1987. El mueble clásico español. Madrid: Cuadernos de Arte Cátedra.

Aguiló, M. P. 1990. "Mobiliario en el siglo XVII", en Mueble español, estrado y dormitorio: 103-128. Madrid: Comunidad de Madrid.

Aguiló, M. P. 1993. El mueble en España, siglos XVI-XVII. Madrid: CSIC y Ed. Antiquaria. Aguiló, M. P. 2008. "Aproximaciones al estudio del mueble novohispano en España", en El mueble del siglo XVIII: Nuevas aportaciones a su estudio: 19-31. Barcelona: Associació per a l'estudi del moble.

Arce, A. 2001. Árboles meliferos nativos de Mesoamérica. El Salvador: Universidad de El Salvador.

Armella, V. 1994. Labores de ebanistería en la Nueva España. México: Grupo Gutsa.

Armijo Torres, R, 2005. "Arqueología e historia del sistema de aprovisionamiento de agua potable para la ciudad de México durante la época virreinal: acueductos de Chapultepec y Santa Fe" en Diario de Campo. Suplemento N. 36: 81-111. México: Instituto Nacional de Antropología e Historia.

Armiño, M. 1966. "Hernando Cortés: exequias, almoneda e inventario de sus bienes, con otras noticias de su familia". Anuario de Estudios Americanos XXIII.

Beck, H. R. 2007.The Woodbook. Köln/Nueva York: Taschen.

Benítez, F. 1953. La Vida Criolla en el Siglo XVI. México: Colegio de México.

Blanco, C. 1919. Mil y una recetas de artes y oficios. México: C. Bouret.

Carrillo y Gariel, A. 1957. Evolución del mueble en México. México: Instituto Nacional de Antropología e Historia. 
Castellanos, C. 1990. "El mueble del Renacimiento", en Mueble español, estrado y dormitorio: 59-84. Madrid: Comunidad de Madrid.

Castelló, T. 1972. "Maque o laca". Artes de México 153: 33-81.

Códice Florentino. 1979 [Siglo XVI]. (Manuscrito mexicano, Biblioteca Medicea Laurenziana, Florencia), Edición facsimilar. México: Gobierno de la República.

Códice Mendoza 1938 [1541-1542]. (Manuscrito mexicano conocido como Códice Mendocino. Bodleian Library, Inglaterra). J. Cooper Clark. Edición facsimilar. Londres: Ediciones Oxford.

Códice Osuna. 1976 [1565]. (Manuscrito mexicano conocido como Códice Osuna o Pintura del gobernador, alcaldes y regidores de México. Biblioteca Nacional de Madrid). Edición facsimilar. Madrid: Ministerio de Educación y Ciencia.

Corrales, J. M. 1998. "El mueble mexicano del siglo XIX y sus influencias europeas", en G, Codinach, L, Cortina, et al., Intimidad moda y diseño. México entrañable: 108-133. México: Museo de la Ciudad y Gobierno de la Ciudad de México.

Corrales, J. M. 2000. Lazos de sangre. Retrato mexicano de familia. México: Museo de la Ciudad / Gobierno de la Ciudad de México.

Corrales, J. M. 2006. "Escritorios, Papeleras y Contadores, los mal llamados Bargueños". Descubrir el Arte 88: 120-121.

Couturier, E. 2005. "Plata cincelada y terciopelo carmesí: una casa para el conde de Regla", en E. Quiroz, F. García, et al., Historia de la vida cotidiana en México. Vol. III: 155178. México: Colegio de México y Fondo de Cultura Económica.

Cronquist, D. 1981. An integrated system of classification of flowering plants. Nueva York: Columbia University Press.

Curiel, G. 1994. "Ajuar doméstico del tornaviaje", en E. Vargaslugo, C. Martínez, et al., México en el mundo de las colecciones de arte. Nueva España: Vol. 1: 157-210. México: Azabache.

Curiel, G. 1999. "Los biombos novohispanos: escenografía del poder y transculturación en el ámbito doméstico", en B. Navarrete, A. Leroy, et al., Viento detenido: 9-32 México: Museo Soumaya.

Curiel, G. 2003. "Formas, costumbres y rituales cotidianos de las elites novohispanas a través de los objetos de la cultura material", en D. B. Warren, J. Gutiérrez, et al., Grandeza Mexicana Virreinal. 23-43. Catálogo de exposición. Houston: Museum of Fine Arts.

Curiel, G. 2005. "Ajuares domésticos. Los rituales de lo cotidiano", en M. C, León, M, Fernández, et al., Historia de la vida cotidiana en México. Vol. II: 81-108. México: Colegio de México y Fondo de Cultura Económica.

Curiel, G. 2006. "Los ajuares domésticos novohispanos", en E. Turrent, A. Ortiz, et al., Museo Franz Mayer, 20 años de Arte y Cultura en México. 320-366. México: Banco de México / Editorial Chapa.

Checa, F. 1988. "La imagen impresa en el renacimiento y manierismo", en J, Carreter y V. Bozal, El grabado en España. Vol. I: 11-202. Madrid: Espasa Calpe.

Diccionario de Autoridades. 1979. Real Academia Española, 1726-1739. Ed. Facsimilar. Madrid: Gredos.

Diccionario de americanismos. 1982. Barcelona: Ramón Sopena.

Diccionario de la Lengua Española. 2001. Madrid: Real Academia Española.

García Salinero, F. 1968. "El léxico de un ingeniero español del siglo XvI". Hispania 54 (3): $34-45$.

Gómez, F. 1983. El mobiliario y la decoración en la Nueva España en el siglo XVI. México: Universidad Nacional Autónoma de México. 
Hendrick, U. P. 1972. Edible plants of the World. Reino Unido: Dover Publications.

Hernández, F. 1959 [Siglo XVI]. Historia natural de Nueva España. Edición facsimilar. México: Universidad Nacional Autónoma de México.

Hobbs, E.W. 1943. Enchapado de maderas diversas. Buenos Aires: Editorial Albatros.

Lewis, G. 2005. Legumes of the World. Londres: The Royal Botanic Garden.

López Moreno, M. A. 2005. "Notas para la recuperación histórica de las fábricas, Isla de León”. Revista Cultural del Ateneo de Cádiz 5: 47-56.

Lorea-Hernández, F.G. 2005. "Nuevas especies de Lauraceae en México". Acta Botánica Mexicana 71: 61-87.

Los Municipios de Oaxaca, 1988. "Enciclopedia de los Municipios de México". México: Secretaría de Gobernación. Centro Nacional de Estudios Municipales, Gobierno del Estado de Oaxaca.

Loyzaga, J. 1985. "La taracea en México", en C. Aguilera, E. Vargaslugo, et al., El mueble mexicano, historia, evolución e influencias: 73-90. México: Fomento Cultural Banamex.

Martínez, F. 1974. Pegamentos, gomas y resinas en el México prebispánico. México: SepSetentas.

Martínez Del Río, M. 1990. "Ficha de catalogación n. 204”, en México. Esplendor de treinta siglos: 440. México: Amigos de las Artes de México. Nueva York: The Metropolitan Museum of Arts.

Meleón Gavilanes, P. 1990. Oro y plata de las Indias en la época de los Austrias. Madrid: Fundación ICO

Montemayor, C. 2007. Diccionario del nábuatl en el español de México. México: Universidad Nacional Autónoma de México / Gobierno del Distrito Federal.

Muñoz, L. 1977. José de Pineda Ibarra y la primera imprenta de Guatemala. Guatemala: Editorial José de Pineda Ibarra.

Muñoz Camargo, D. 2000 [1584]. Descripción de la ciudad y provincia de Tlaxcala. Edición facsimilar. México: Gobierno de Tlaxcala / COLSAN.

Ovando, C. 1962. "La taracea mexicana". Artes de México 118: 56-71.

Pérez, S. 1990. La laca mexicana. Madrid: Alianza Editorial.

Prieto, L. 2006. "El huizache, aromas del pasado y porvenir". México Forestal 31: 10-15.

Rico Arce, L. 2005. "Nombres nuevos para dos especies mexicanas de acacia". Acta Botánica Mexicana 71: 89-92.

Rodríguez Bernis, S. 2006. Diccionario de mobiliario. Madrid: Ministerio de Cultura.

Rojas, T.; E. L. Rea y C. Medina 1998. Vidas y Bienes Olvidados, Testamentos Indigenas Novohispanos. México: Ediciones del Lirio.

Romero de Terreros, M. 1913. La casa del conde de Regla. México: Sociedad Mexicana de Geografía y Estadística.

Romero de Terreros, M. 1957. Una casa del siglo XVIII en México. La del conde de San Bartolomé de Xala. México: Imprenta Universitaria.

Romero de Terreros, M. 1982. Las artes industriales en la Nueva España. México: Banco Nacional de México.

Sahagún, Fray B. de. 1993 [1561-1565]. Primeros memoriales. Edición facsimilar. University of Oklahoma Press.

Sahagún, Fray B. de. 1956 [Siglo XVI]. Historia General de las Cosas de la Nueva España. Edición facsimilar, México: Porrua.

Schurtz, W. L. 1992. El galeón de Manila. Madrid: Ediciones de Cultura Hispánica.

Segarra, E. 1911. Los Gremios. Barcelona: Altes y Alabart.

Shorto, S.; D. Fane y E. J. Sullivan 1996. Converging Cultures. Art E Identity in Spanish America. Catálogo de exposición. Nueva York: The Brooklyn Museum. 
Thiele, E. M. 1982. El Maque. Estudio histórico sobre un bello arte. Michoacán: Instituto Michoacano de Cultura.

Torre y del Cerro, A. 1964. Testamentaría de Isabel la Católica. Barcelona: sn.

Ullóa, A. de. 1784. La campaña de las Terceras. Fondo documental Islas Azores, fols.: 13-21. Archivo del Museo Naval de Madrid.

Urdiales, J. 2006. Diccionario de voces y expresiones populares y rurales en la obra de Miguel Delibes. Valladolid: Instituto Castellano Leonés de la Lengua / El Norte.

Zahar, L. 2000. Taracea islámica y mudéjar. Colección Usos y Costumbres. México: Museo Franz Mayer / Artes de México.

\section{DOCUMENTOS}

Carta del Administrador de Alcabalas de Villa Alta a la Dirección de Alcabalas, 30 de Abril de 1804. Archivo General de la Nación, México: Alcabalas, caja 1192.

Cuadernos de viento de San Ildefonso de Villa Alta: 1791, 1792, 1793 y 1794. Archivo General de la Nación, México.

Inventario de los bienes del Teniente Coronel de Infantería D. Joseph Mariano Martínez, 1766. Archivo del Estado de Oaxaca: Leg. 34, exp. 8, foja, 28.

Inventario de los bienes de Don Pedro Canon De Amaya, 1687. Archivo del Estado de Oaxaca: Leg. 7, exp. 4, foja 15.

Inventario de los bienes de Alférez Nicolás Oñes de Gamboa, 1683. Archivo del Estado de Oaxaca: Leg, 4, exp. 14, foja 20.

Inventario de los bienes de Don Juan Martín de Villalonga, 1682. Archivo del Estado de Oaxaca: Leg. 4, exp. 2, foja 10.

Inventario de los bienes de Don Alonso Sarmiento de Sebreros, 1712. Archivo del Estado de Oaxaca: Leg. 13, exp. 22, fojas 14 y 19.

Inventario de bienes de Don Bartolomé Groso, 1726. Archivo del Estado de Oaxaca: Leg. 14, exp. 14, foja 12.

Libros Reales de San Ildefonso de Villa Alta, 1790 y 1795. Archivo General de la Nación, México.

Memoria y valúo de los bienes que quedaron por fin y muerte del señor Marqués de Santa Fe de Guardiola IV, 19 de Febrero de 1793. Archivo de Notarías de México, Mariano Zepeda, n.․․ 746 .

Testimonio sobre la compra de una casa en Villa Alta por Don Pedro de Ortega (17861790). Archivo General de la Nación, México. Vol. 30, exp. 1, ff. 1-5v.

Fecha de recepción: 4 de noviembre de 2008

Fecha de aceptación: 15 de febrero de 2009

RDTP, vol. LXVI, n. ${ }^{\circ}$ 1, pp. 57-88, enero-junio 2011, ISSN: 0034-7981, eISSN: 1988-8457, doi: 10.3989/rdtp.2011.03 